\title{
Loss of E-Cadherin-Dependent Cell-Cell Adhesion and the Development and Progression of Cancer
}

\author{
Heather C. Bruner ${ }^{1}$ and Patrick W.B. Derksen ${ }^{2}$ \\ ${ }^{1}$ Department of Medicine, University of California at San Diego, La Jolla, California 92093 \\ ${ }^{2}$ Department of Pathology, University Medical Center Utrecht, Utrecht 3584CX, The Netherlands \\ Correspondence: pderksen@umcutrecht.nl
}

Classical cadherins are the key molecules that control cell-cell adhesion. Notwithstanding this function, it is also clear that classical cadherins are more than just the "glue" that keeps the cells together. Cadherins are essential regulators of tissue homeostasis that govern multiple facets of cellular function and development, by transducing adhesive signals to a complex network of signaling effectors and transcriptional programs. In cancer, cadherins are often inactivated or functionally inhibited, resulting in disease development and/or progression. This review focuses on E-cadherin and its causal role in the development and progression of breast and gastric cancer. We provide a summary of the biochemical consequences and consider the conceptual impact of early (mutational) E-cadherin loss in cancer. We advocate that carcinomas driven by E-cadherin loss should be considered "actin-diseases," caused by the specific disruption of the E-cadherin-actin connection and a subsequent dependence on sustained actomyosin contraction for tumor progression. Based on the available data from mouse and human studies we discuss opportunities for targeted clinical intervention.

\section{INTRODUCTION}

Classical cadherins are transmembrane-spanning adhesion molecules containing five calcium-dependent extracellular (EC) domains that confer homotypic interactions and a cytoplasmic tail that binds to a number of effectors to transduce physical and biochemical signals to the cell (reviewed in Lecuit and Yap 2015). Vertebrate classical cadherins can be separated into two related families; the type I and type II cadherins (Nollet et al. 2000). Specification of the two families is based on the presence of a distinct histidine-alanine-valine (HAV) sequence in the first EC domain, which is important for cadherin engagement (Ozawa et al. 1990; Williams et al. 2002). In total, five type I classical cadherins can be defined based on the above criteria. While their names were initially based on the cell type in which expression was first described, a consensus nomenclature now defines the classical cadherins as $\mathrm{CDH} 1$ (E-cadherin), $\mathrm{CDH} 2$ (N-cadherin), CDH3 (P-cadherin), CDH4 (Rcadherin), and CDH15 (M-cadherin) (Table 1).

Editors: Carien M. Niessen and Alpha S. Yap

Additional Perspectives on Cell-Cell Junctions available at www.cshperspectives.org

Copyright (C) 2018 Cold Spring Harbor Laboratory Press; all rights reserved; doi: 10.1101/cshperspect.a029330

Cite this article as Cold Spring Harb Perspect Biol 2018;10:a029330 
H.C. Bruner and P.W.B. Derksen

Table 1. Classical Type I cadherins. Nomenclature, genomic position, and cancer role

\begin{tabular}{|c|c|c|c|c|}
\hline Trivial name & Gene symbol* & Gene location* & Role in cancer & References \\
\hline E-cadherin & CDH1 (Cdh1) & $16 q 22.1(8: 10.66 \mathrm{Mb})$ & $\begin{array}{l}\text { Tumor } \\
\text { suppressor }\end{array}$ & $\begin{array}{l}\text { Berx et al. 1995; Guilford et al. 1998; } \\
\quad \text { Perl et al. 1998; Derksen et al. } 2006\end{array}$ \\
\hline N-Cadherin & $\mathrm{CDH} 2(\mathrm{Cdh} 2)$ & $18 \mathrm{q} 12.1(18: 16.58 \mathrm{Mb})$ & Oncogene & Islam et al. 1996; Hazan et al. 1997a \\
\hline P-cadherin & CDH3 (Cdh3) & $16 q 22.1(8: 10.65 \mathrm{Mb})$ & Multiple & $\begin{array}{l}\text { Radice et al. 1997; Peralta Soler et al. } \\
\text { 1999; Paredes et al. } 2004\end{array}$ \\
\hline R-cadherin & CDH4 (Cdh4) & $20 q 13.33(2: 17.94 \mathrm{Mb})$ & $\begin{array}{l}\text { Tumor } \\
\text { suppressor }\end{array}$ & Agiostratidou et al. 2009 \\
\hline M-cadherin & CDH15 (Cdh15) & $16 q 24.3(8: 122.84 \mathrm{Mb})$ & $\begin{array}{l}\text { Tumor } \\
\text { suppressor }\end{array}$ & $\begin{array}{l}\text { Cool and Jolicouer 1999; Yamada et al. } \\
2007\end{array}$ \\
\hline
\end{tabular}

*Information in parentheses depicts nomenclature (Gene symbol) or chromosomal positioning (Gene location) for Mus musculus. $\mathrm{Mb}=$ Megabase.

Together with the EC domains, the cytosolic tail of E-cadherin forms the core of a mechanotransduction and signaling hub called the adherens junction $(\mathrm{AJ})$, which connects intercellular contacts to the actin and microtubule cytoskeleton (reviewed in Leckband and de Rooij 2014). For these functions, classical cadherins depend on the catenins, which are essential mediators of force and biochemical signals. Most proximal to the intracellular face of the cell membrane, cadherins bind to p120-catenin (CTNND1) (Ireton et al. 2002; Davis et al. 2003; Nanes et al. 2012), which was originally identified as a substrate of oncogenic Src (Reynolds et al. 1989). Cadherin association with p120-catenin (p120) is essential for stabilization and function of the classical cadherin (Reynolds et al. 1994; Yap et al. 1998; Ireton et al. 2002; Davis et al. 2003; Nanes et al. 2012). Linkage of classical cadherins to the actin cytoskeleton is enabled through binding to CTNNB1 ( $\beta$-catenin). Although the exact working mechanism underlying actin linkage still remains uncertain, it appears that monomeric $\alpha$-catenin (CTNNA1) binds to $\beta$-catenin to link the AJ to filamentous $(\mathrm{F})$-actin, whereas dimeric $\alpha$-catenin associates directly with the actin cytoskeleton independently of the cadherin (reviewed in Meng and Takeichi 2009 and Shapiro and Weis 2009).

Evidence for a direct function of E-cadherin in cell-cell adhesion was provided when the full-length cDNA of E-cadherin was cloned and expressed in fibroblasts that do normally not express E-cadherin. This experiment in- duced morphological changes when forcing these cells to grow in tight clusters under calcium-dependent conditions (Nagafuchi et al. 1987). Knockout studies subsequently showed that E-cadherin was essential for development, by showing that homozygous inactivation of Cdh1 in mice led to embryonic lethality caused by a failure of trophectoderm formation (Larue et al. 1994).

Within this review we will focus on the role of E-cadherin in breast and gastric cancer, because in contrast to the other type I cadherins, there is causal and clinically relevant evidence that E-cadherin functions to repress tumor development and progression in these cancer types (Berx et al. 1995; Guilford et al. 1998; Perl et al. 1998; Derksen et al. 2006). Also, the downstream effectors controlled by E-cadherin might not be identical amongst the type I classical cadherins. Hence, this review will emphasize the observations made in breast cancer due to the overwhelming data that depict a tumor development and invasion suppressor role for E-cadherin in this malignancy.

\section{E-CADHERIN IS ESSENTIAL FOR MAMMARY GLAND FORM AND FUNCTION}

The mammary gland mainly consists of two cell types; apical luminal epithelial cells that produce milk and basal myoepithelial cells that provide a linkage to the mammary stroma and facilitate milk excretion during lactation. Next to these major cell types the mammary gland also 
contains specialized (luminal) lobulo-alveolar cells and likely two progenitor cell types that either control mammary gland formation and/or hormone-dependent alveolar development (reviewed in Regan and Smalley 2007). Cadherin expression in the differentiated cells of the mammary gland is well-defined and celltype specific (Fig. 1). E-cadherin is expressed by luminal epithelial cells, whereas the myoepithelial cell express P-cadherin (Daniel et al. 1995). Expression of either cadherin in the progenitor or mammary stem cell populations, however, is still unclear, mainly because the exact identity and architectural positioning of these elusive cells remains ill-defined. Current evi-

A

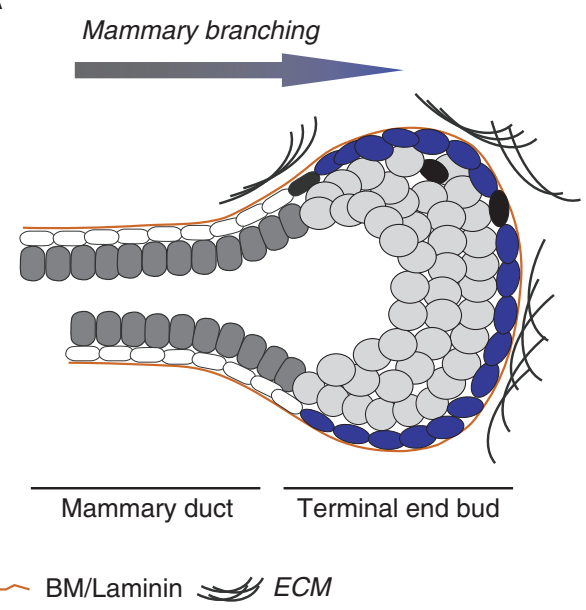

Luminal epithelial cell (E-cadherin, CK8/18)

Myoepithelial cell (P-cadherin, CK5/14)

Stem or progenitor cell

Body cell (E-cadherin) CAP cell (P-cadherin) dence points toward a basal and P-cadherin expressing progenitor cell responsible for mammary formation and branching morphogenesis (see Fig. 1), whereas alveolar progenitor cells probably are luminal-type cells giving rise to E-cadherin positive decedents (reviewed in Visvader and Stingl 2014). Conditional inactivation in the mammary gland using knockout mouse models has shown that E-cadherin is essential for this organ. E-cadherin loss resulted in luminal cells undergoing apoptosis and clearance (Boussadia et al. 2002; Derksen et al. 2011).

In line with the differential cadherin expression, it was shown that inhibition of P-cadherin using neutralizing antibodies resulted in a par-

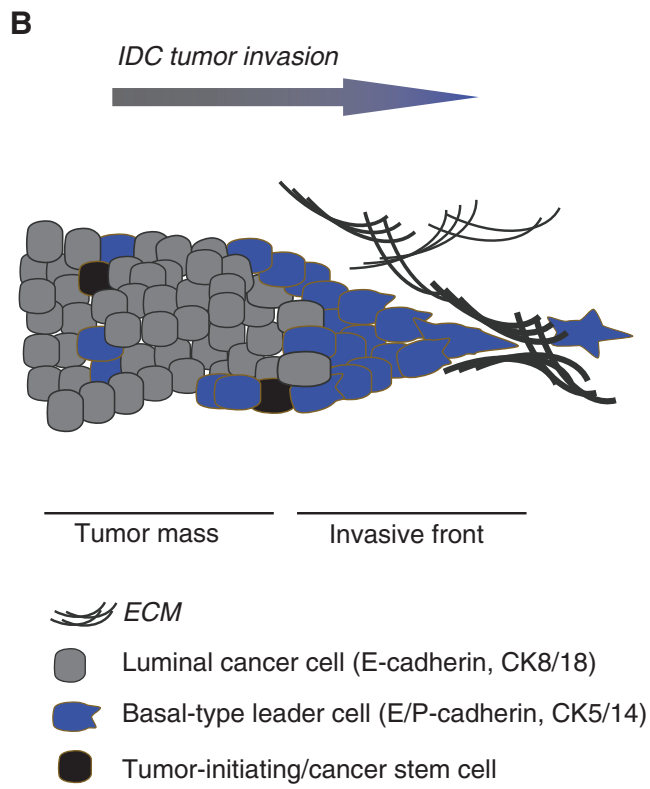

Figure 1. Mammary gland development and breast cancer invasion. (A) Epithelial lineage commitment during mammary gland development. Shown is a schematic representation of a mammary duct with its differentiated myoepithelial (white cells) and luminal epithelial (gray) cells. The Terminal End Bud (TEB) is a structure at the leading front of a branching mammary structure during postnatal development. Here, both cell lineages are presumably generated through cell populations called "Cap cells" and "Body cells," which express either Pcadherin and/or E-cadherin, respectively. Myoepithelial cells are basal in origin and produce laminins that constitute the basement membrane (BM; brown line). The enigmatic mammary stem or progenitor (black) cells may reside in the TEB and/or the resting mammary duct. Myoepithelial and luminal cell markers are indicated. (B) A scenario for late (epigenetic) inactivation of invasive ductal breast cancer (IDC). Cartoon depicting an invasive breast cancer strand mostly expressing luminal markers such as cytokeratin (CK) 8 and E-cadherin. Recent studies have highlighted the potential importance of focal (and transient?) acquisition of basal characteristics, which might underpin epigenetic E-cadherin inactivation leading to invasion and metastasis. 
tial but specific disruption of the basal cells in the developing mammary gland (Daniel et al. 1995). Subsequent genetic knockout studies in mice revealed that although P-cadherindeficient mice were viable and fertile, the resulting female mice showed precocious alveolar differentiation and mammary hyperplasia, especially after multiple pregnancies (Radice et al. 1997). Neither mammary-specific E-cadherin nor P-cadherin knockout mice developed tumors (Radice et al. 1997; Boussadia et al. 2002; Derksen et al. 2011). Mammary-specific inactivation and the resulting induction of apoptosis in luminal cells showed that (1) Ecadherin loss is not tolerated in the mammary gland (Boussadia et al. 2002; Derksen et al. 2011) and as such is an unlikely candidate driver event in tumor development; and (2) luminal mammary cells lack a functional redundant cadherin to compensate for E-cadherin loss. This is of interest because E-cadherin inactivation in postnatal skin is tolerated because of Pcadherin redundancy (Tinkle et al. 2004; Tunggal et al. 2005), implying a tissue-specific and context-dependent role for E-cadherin in the mammary gland. In short, we propose that a protumorigenic event that overrides the apoptotic signals induced by E-cadherin loss has to precede or coincide with inactivation of the wild-type $\mathrm{CDH} 1$ allele, which is a frequent event in multiple cancer types (reviewed in Strumane et al. 2004).

\section{LOSS OF E-CADHERIN UNDERPINS TUMOR DEVELOPMENT AND PROGRESSION}

At the end of the previous century it became apparent that the pivotal role of E-cadherin during normal epithelial function might form the basis for its function as a tumor suppressor. In landmark papers by the Birchmeier and Van Roy groups, it was shown that inhibition of E-cadherin function was sufficient to induce dissociation and invasion of cancer cells (Behrens et al. 1985,1989; Vleminckx et al. 1991). Moll et al. (1993) subsequently showed clinical relevance by demonstrating that a major breast cancer subtype called invasive lobular carcinoma
(ILC) was characterized by E-cadherin deficiency, whereas most other breast cancer subtypes expressed E-cadherin. Genetic evidence identified inactivating somatic $\mathrm{CDH} 1$ mutations in approximately $50 \%$ of all ILC samples analyzed (Berx et al. 1995,1996). Interestingly, apart from ILC, half of all diffuse gastric carcinomas (DGC) analyzed also harbored somatic inactivating CDH1 mutations (Muta et al. 1996; Becker et al. 1994). Follow-up studies subsequently identified germline inactivating E-cadherin mutations in DGC (Guilford et al. 1998) and ILC (Masciari et al. 2007), suggesting a unique and potential overlapping tumor etiology of these two cancer types.

E-cadherin-inactivating mutations in gastric cancer preferentially cause in-frame deletions caused by skipping of exons 7 or 9 , or occasional frameshift mutations, whereas the majority of somatic E-cadherin mutations in ILC leads to frame shift mutations and mutations inducing premature stops in the extracellular domain (Berx et al. 1998). Alternatively, other cancer types such as prostate, endometrium, and invasive ductal carcinoma (IDC) that show loss of E-cadherin protein expression, retain a wild-type genetic makeup, but display methylation of the E-cadherin promoter (reviewed in Strathdee 2002). In contrast to other key tumor suppressors, no specific hotspots have been identified in the extracellular E-cadherin domain. This, together with the fact that E-cadherin silencing in ILC is caused by a combination of frameshift mutations and loss of heterozygosity (LOH) (reviewed in Berx and Van Roy 2009), suggest that complete E-cadherin loss provides cancer cells with an evolutionary advantage over protein downregulation or functional aberrations. Furthermore, noninvasive lobular carcinoma in situ (LCIS) precursor lesions already showed loss of E-cadherin protein expression (Vos et al. 1997), which is occasionally accompanied by contained germline loss of function mutations (Petridis et al. 2014), indicating that this loss is an early event in lobular cancer.

In 1998, causal evidence that E-cadherin loss drives tumorigenesis was provided in vivo using the Rip1TAG2 mouse model of pancreatic 
cancer (Dahl et al. 1996). In this model inhibition of E-cadherin function using a dominantnegative version that lacked most of the extracellular domains induced invasion and metastasis, whereas forced expression of full length E-cadherin reversed the invasive phenotype (Perl et al. 1998). Although this experiment did not shed light on the intracellular consequences of E-cadherin loss in DGC and ILC, it elegantly showed that E-cadherin was an essential tumor progression suppressor in pancreatic cancer. However, it took another 8 years to directly link E-cadherin loss to the development of ILC. Using tissue-specific mouse models, it was shown that stochastic and somatic E-cadherin inactivation in the mammary gland in combination with loss of p53 led to the formation and progression of mouse ILC (Derksen et al. 2006, 2011). Concomitant loss of p53 was necessary because (1) E-cadherin loss alone is not tolerated in the mouse mammary gland (Boussadia et al. 2002); and (2) conditional p53 knockout in the mammary gland induces formation of noninvasive mammary carcinomas (Liu et al. 2007; Derksen et al. 2011), a prerequisite for studying tumor progression. A similar setup later established Ecadherin loss as a driver of hereditary DGC (HDGC), by showing that combined loss of Ecadherin and p53 in the gastric lineage using Atp4b-Cre mice induced GDC development, tumor invasion, and metastasis (Shimada et al. 2012). A recent CRISPR/Cas9-based tumor progression experiment by the Jonkers group elegantly showed that dual E-cadherin and PTEN inactivation also led to ILC development and progression (Annunziato et al. 2016), indicating that either inactivation of p53 or activation PI3K-dependent signaling synergizes with E-cadherin loss in ILC formation and progression. Supporting this are studies showing that endogenous expression of the oncogenic H1047R Pik3ca mutant in mice leads to luminal features in ER-expressing mammary carcinoma (Van Keymeulen et al. 2015).

In conclusion, it is clear that loss of E-cadherin is causal to tumor development and progression in cancer, most notably in ILC and HDGC.

\section{E-CADHERIN LOSS AND THE EPITHELIAL TO MESENCHYMAL TRANSITION}

E-cadherin expression is mostly restricted to epithelial cells, whereas cells of neural or mesenchymal origin usually express $\mathrm{N}$-cadherin. Epithelial cells are phenotypically dissimilar from mesenchymal cells; from a cancer point of view the latter are more motile and migratory. Because the epithelial to mesenchymal cell transition (EMT) is an essential hallmark of embryonic development, the idea was postulated by leading cancer biologists that epithelial cancers must acquire mesenchymal characteristics for invasion and metastasis (reviewed in Kalluri and Weinberg 2009 and Nieto et al. 2016). Although it appears obvious that an epithelial cancer cell must attain specialized traits to invade and metastasize, it is less clear-cut what the biochemical and cell-receptor prerequisites of such a cell should be. In breast cancer a "cadherin-switch" has been the focus of many laboratories. Cadherin switching in cancer is defined as loss of E-cadherin and expression of $\mathrm{N}$-cadherin during tumor progression (reviewed in Hazan et al. 2004), which will induce or enhance the metastatic capacity of the invading carcinoma cell. Based on a preponderance of experimental evidence, a consensus definition was promoted, stating that a classical EMT should conform to the basic criteria of cadherin switching and the acquisition of additional mesenchymal markers (e.g., expression of Fibronectin and Vimentin). Despite the overwhelming experimental data that support a role for EMT phenomenon in cancer cell invasion and metastasis, evidence supporting EMT as a clinically relevant driver of cancer metastasis is nonetheless scarce (Diepenbruck and Christofori 2016). Classical EMT was also absent from tumors or their metastases in the above described mouse models of ILC and DGB (Derksen et al. 2006, 2011; Shimada et al. 2012). Apart from the obvious EMT hallmark (E-cadherin loss), metastatic cells in these models retained their epithelial characteristics based on luminal cytokeratin expression patterns, and lacked expression of the mesenchymal EMT markers. These findings conform to 
clinicopathological findings in DGC and ILC, where invading cells and their metastases are luminal epithelial-type cancer cells (Vlug et al. 2013a; Mahmud et al. 2015; van der Post et al. 2015). In sum, these data demonstrate that early mutational loss of E-cadherin does not lead to a classical EMT.

In contrast, invasive ductal cancer (IDC) represents $>95 \%$ of all non-ILC breast cancers and is mostly E-cadherin positive (Molland et al. 2004). It is therefore apparent that loss of E-cadherin is not a driver event in IDC but instead occurs late in tumor progression. This secondary E-cadherin loss can be caused by the ever-growing list of miRNAs, and transcriptional repressors such as Slug and Snail (Nieto and Cano 2012). Hence, in IDC, the timing of E-cadherin inactivation and its consequences for the underlying biochemistry and resulting phenotype are clearly different when compared to cancers that are driven by E-cadherin loss such as HDGC and ILC. As mentioned previously, clinical evidence demonstrates that most IDCs appear to express E-cadherin at the invasive front (Moll et al. 1993). However, it is possible that the invading leader cells temporally down regulate E-cadherin, or are subjected to EMT-type mechanisms that cause up-regulation of many other proinvasive molecules such as P-cadherin (Albergaria et al. 2011). Indeed, recent data by the Ewald laboratory have suggested that local induction of a basal-type transcriptional program in breast cancers such as IDC may underpin invasion and metastasis (Cheung et al. 2013). In the case of IDC this would imply that invasive leader cells are spatiotemporally reprogrammed to inappropriately use their intrinsic mammary capacity to transdifferentiate between epithelial and mesenchymal cell types (reviewed in Regan and Smalley 2007), a feature that might be governed by microenvironmental cues (Chen et al. 2013; Di-Cicco et al. 2015) (see Fig. 1B). These interesting insights will require a comprehensive specification, follow-up, and functional characterization of the adhesion receptors involved to delineate the involvement of luminal to basal transdifferentiation in breast cancer progression.
In short, epigenetic silencing of E-cadherin is likely driven by specific transcriptional programs and appears to be a late event in cancer, whereas loss of E-cadherin and subsequent inactivation of the wild-type allele represent an early driver of specific tumor development and progression. It therefore suggests that the biochemical wiring of these two inactivation mechanisms, as well as their functional and phenotypic consequences are different, and that the resulting malignancies should be clinically treated as such.

\section{ALTERNATIVE AND INDIRECT MECHANISMS TO SILENCE E-CADHERIN IN CANCER}

A causal relationship between E-cadherin loss and the development of ILC or HDGC is not always overtly obvious. For example, approximately $5 \%-10 \%$ of lobular breast cancer cases retain E-cadherin expression despite the phenotypical ILC appearance (Rakha et al. 2010; Canas-Marques and Schnitt 2015). Moreover, $50 \%$ of all ILC cases show loss of E-cadherin expression in the absence of inactivating CDH1 mutations (Dabbs et al. 2007; Christgen and Derksen 2015). Because approximately $50 \%-70 \%$ of the affected HDGC families show no evidence of a $C D H 1$ inactivating mutation, it is likely that other pathogenic variants may be present in as yet unidentified DGC-associated susceptibility genes (Oliveira et al. 2006; Kaurah et al. 2007). It thus appears that mechanisms other than genetic and epigenetic silencing of E-cadherin contribute to aberrant E-cadherin expression and subsequent impairment of AJ function.

\section{Identification of $\alpha$-catenin as an ILC and HGDC tumor suppressor}

A likely secondary mechanism that induces AJ dysfunction and a subsequent constitutive deregulation of actin function is $\alpha$-catenin loss. Studies in breast cancer cell lines have shown that bi-allelic mutational inactivation of CTNNA1 is the underlying cause of dysfunctional AJs. As a result, cells show a noncohesive 
cellular phenotype similar to lobular breast cancer cells (Hazan et al. 1997b; Hollestelle et al. 2010). These findings were complemented by the identification of germline truncating CTNNA1 mutations (with no evidence for $\mathrm{CDH} 1$ inactivation) in HDGC (Majewski et al. 2013). Interestingly, we have obtained preliminary experimental evidence that $\alpha$-catenin loss in E-cadherin proficient breast cancer cell lines induces Rho/Rock-dependent anchorage independence and tumor progression of conditional p53-deficient mammary progenitors in vivo, similar to E-cadherin inactivation (De Groot et al. unpubl.). Together, these findings imply that silencing of $\alpha$-catenin represents an infrequent but driving event that mimics E-cadherin loss and leads to AJ dysfunction and subsequent cellular responses including constitutive Rockdependent actin polymerization, in human and mouse ILC alike.

AJ loss-of-function on p120 leads to a mesenchymal-type invasive tumor type

As mentioned previously, p120 is essential for the stabilization and function of classical cadherins (Yap et al. 1998; Davis et al. 2003) (also see Fig. 2A). Similar to E-cadherin loss, p120 inactivation in the mammary gland is not tolerated and leads to apoptosis and sloughing of mammary ductal epithelial cells (Kurley et al. 2012). Given the impact of $\alpha$-catenin loss on junctional integrity and the potential outcome in cancer, one might assume a similar result on inactivation of p120. Surprisingly, p120 knockout in the skin, oral cavity, esophagus, and squamous forestomach does not seem to require p53 inactivation and induced either hyperplasia or squamous cancer types in these tissues (Stairs et al. 2011; Perez-Moreno et al. 2008). To circumvent the induction of apoptosis in the mammary gland, somatic p120 loss was combined with p53 knockout, which resulted in overt mammary carcinoma invasion and metastasis when compared to p53 inactivation alone (Schackmann et al. 2013). Interestingly, although p120 showed a clear role in suppression of invasion, tumors that developed were not lobular but instead displayed an EMT-like phe- notype with mesenchymal/sarcomatoid and metaplastic features. Follow-up studies showed that p120 loss was dominant over E-cadherin inactivation, because mammary-specific triple knockout of p120, E-cadherin and p53 in whey acidic protein (WAP) Cre recombinasedriven female mice promoted the development of basal, EMT-type metastatic mammary tumors (Tenhagen et al. 2016).

Potential roles for junctional complexes other than the $\mathrm{AJ}$ in the maintenance of cell-cell adhesion and tutor suppression

Tight junctions (TJs) regulate adhesion and epithelial permeability, a barrier feature that is often disturbed in cancer (reviewed by Martin et al. 2014). TJs are located apically from AJs at the border of the apical and basolateral membrane domains of epithelial cells. These junctions consist of transmembrane proteins such as claudins and occludin that determine the barrier properties of these junctions, and cytosolic linker proteins such as Zonula Occludens (ZO) proteins and Cingulin that provide linkage to the actin cytoskeleton and indirectly connect the TJs and AJs (see Furuse 2010 for detailed information). Maturation of the TJ is regulated by cytosolic mediators of polarity; aPKC, PAR3, and PAR6 (Suzuki and Ohno 2006). Although it is unclear whether TJ genes are mutationally inactivated in breast cancer, several TJ proteins were found to be down-regulated or absent in advanced tumors. Interestingly, analogous to E-cadherin, absence of Claudin-7 (CLDN7) is evident in both LCIS and ILC and correlates with histological grade in IDC (Kominsky et al. 2003; Sauer et al. 2005), suggesting a role in tumor development and progression. Likewise, expression of Zona Occludens 1 (ZO1; TJP1) was found to be reduced or lost in the majority of breast cancers and correlated with reduced E-cadherin staining (Hoover et al. 1998), thus suggesting tumor suppressor activity. Since TJ components have also been found overexpressed in certain malignancies, there is currently no consensus on how TJ members are involved in tumor development and progression. However, recent evidence 
A
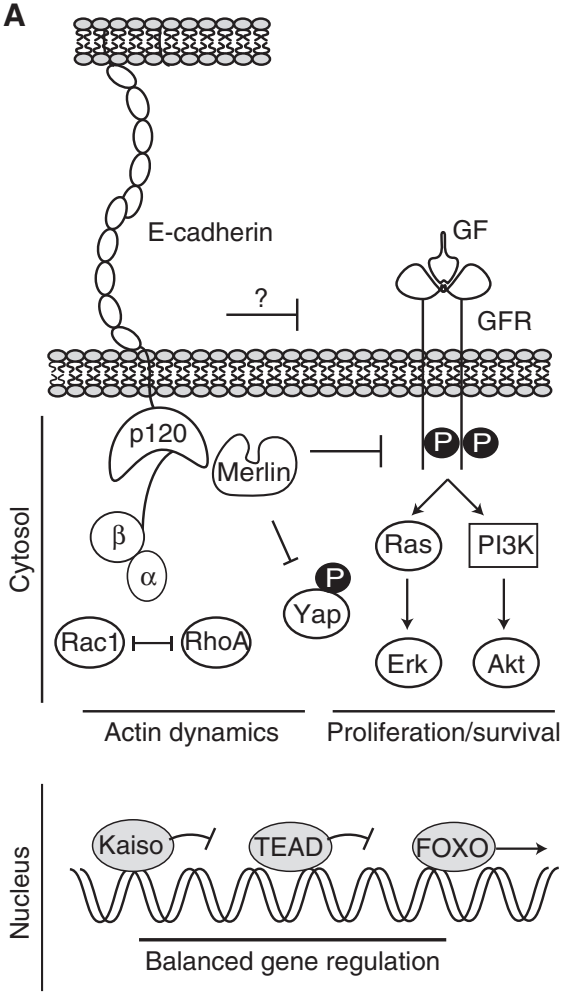

Normal tissue homeostasis
B

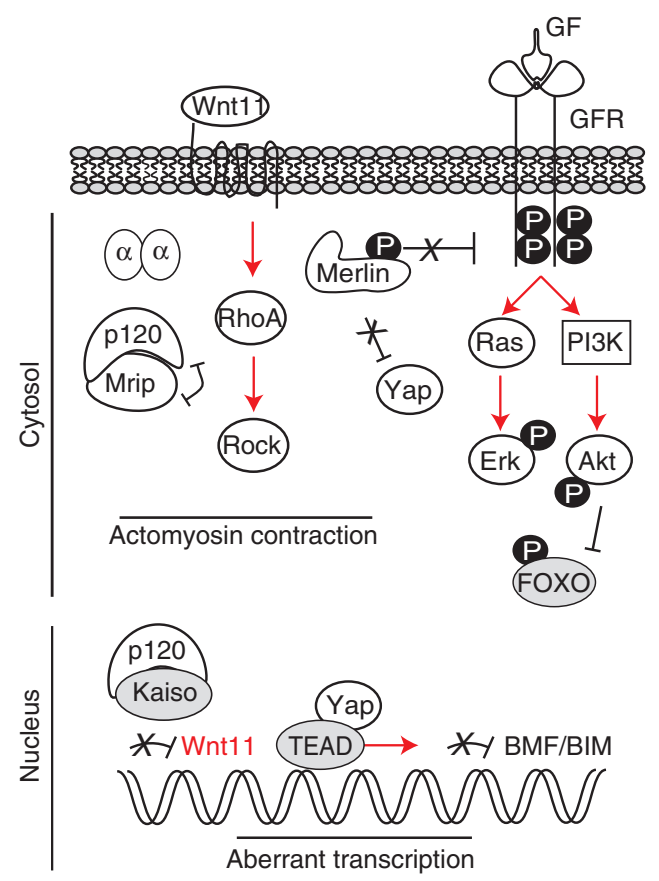

$\overline{\text { Anchorage-independent tumor growth/survival }}$

Figure 2. Biochemical, transcriptional and phenotypical consequences of mutational E-cadherin in cancer. $(A)$ E-cadherin and the adherens junction (AJ) control epithelial homeostasis through a balanced regulation of actin dynamics, gene regulation and proliferation/survival. The simplified cartoon depicts the main players involved. First, the AJ connects the cell membrane to the actin cytoskeleton through intricate control of a cadherin, catenin and RhoGTPase interplay at the cell cortex and in the cytosol. Second, growth factor receptor (GFR) signaling and YAP-dependent proliferation is dampened by NF2/Merlin, which is complexed with the AJ. Finally, transcriptional repression by Kaiso and modulation by FOXO is tightly regulated caused by the presence of homeostatic AJ and GFR reciprocity. (B) Early mutational inactivation of E-cadherin cancer leads to oncogenic stimuli. Upon AJ dismantling, p120 translocates to the cytosol where it binds and inactivates myosin phosphatase Rho-interacting Protein (MRIP), leading to derepression of RhoA and Rock. In contrast, $\beta$-catenin is uncoupled and largely degraded by the proteasome, whereas $\alpha$-catenin resides in the cytosol as dimer. The functional role in cancer of the latter event is as yet undefined. Uncoupled p120 also translocates to the nucleus to bind to and relieve transcriptional repression by Kaiso, leading to expression of specific target genes. In case of Wnt11, this promotes autocrine activation of RhoA. Together, this drives constitutive low level actomyosin contraction in E-cadherin mutant cancer cells. AJ loss also leads to cytosolic retention and a conformational change in NF2/Merlin, an event that results in derepression and/or hypersensitization of growth factor (GF)induced activation of the GFR. Concomitant with the Rock-induced actomyosin contraction, uncoupling (and phosphorylation?) of NF2/Merlin leads to activation of YAP and TEAD-mediated transcriptional activation of its gene targets. Finally, increased GFR signals hyperactivate RAS/MAP Kinase and PI3K/AKT signals. Phosphorylation of AKT inhibits FOXO, leading to cytosolic retention and repression of FOXO-dependent transcription of the proapoptotic BMF and BIM. Altogether, these activated signals (depicted with red arrows) are oncogenic in E-cadherin mutant cells and control anchorage-independent tumor growth and survival, ultimately leading to tumor cell metastasis. 
showed that inhibition of the TJ-associated polarity protein PAR3 in mice enhanced invasion and metastasis of oncogene-induced breast cancer (Xue et al. 2012; McCaffrey et al. 2012). In these studies PAR3 inhibition did not induce a classical EMT, but clearly attenuated E-cadherin expression and AJ stability. However, in the context of oncogenic RAS, PAR3 loss led to a more basal and cytokeratin 14-expressing tumor cell type (McCaffrey et al. 2012), supporting a luminal-to-basal transition scenario. The absence of ILC formation in the aforementioned studies might be caused by the oncogene-driven background, because loss of E-cadherin in the MMTV-PyMT and MMTV-ErbB2 mouse models also does not lead to ILC (R. Kemler, pers. comm.). In conclusion, it appears that overexpression of growth factor receptors or oncogenic RAS/RAF/SRC signals do not provide the cues that underpin the typical E-cadherin loss-type tumors, such as HDGC and ILC. In contrast, specific aberrations in PI3K signals (Annunziato et al. 2016) or p53 loss (Derksen et al. 2006; Shimada et al. 2012) seem to provide the correct instigating hit to allow for E-cadherin loss thus driving carcinoma development and progression that is typical for early E-cadherin inactivation.

The architecture of the desmosome (DS) resembles that of the $\mathrm{AJ}$ in that they are also comprised of cadherins and armadillo-type proteins that connect the DS to the underlying intermediate filaments. Desmogleins (DSG) and desmocollins (DSC) are nonclassical cadherins that mediate adhesion through interactions of their ectodomains. Linkage with the intermediate filament cytoskeleton is controlled by plakoglobin (aka $\gamma$-catenin or JUP) and the plakophilins (PKP) that interact with the IF binding protein desmoplakin (reviewed by Delva et al. 2009). Interestingly, plakoglobin is highly similar to, and can in part functionally replace, $\beta$-catenin (McCrea et al. 1991; Butz et al. 1992), whereas PKP4 (p0071) is a p120 family member (Hatzfeld and Nachtsheim 1996), exemplifying the substantial similarity of the two junctional complexes. Like the AJrelated catenins, DS components have been associated with tumor suppressor as well as on- cogenic properties (reviewed in Dusek and Attardi 2011). For example, DSG2, DSG3, or PKP3 expression was found to be increased in several cancer types and correlated with reduced patient survival (Furukawa et al. 2005; Chen et al. 2007; Brennan and Mahoney 2009). In contrast, reduction or loss of expression of several DS components (DSG1-3; DSC2 and DSC3; JUP and PKP1-3) has been linked to advanced tumor grade and poor survival in various carcinomas including skin, head and neck, prostate, lung, gastric, and breast (Tada et al. 2000; Klus et al. 2001; Winn et al. 2002; Shiina et al. 2005; Andreu et al. 2006; Akai et al. 2006). In line with these findings is the recent observation that DSG3 controls E-cadherin membrane trafficking (Moftah et al. 2016). Loss of desmosomal proteins may be induced through epigenetic mechanisms (Oshiro et al. 2005), suggesting that the mode of inactivation may reflect timing of the event, as is the case for E-cadherin. Although there is currently little information regarding mutational inactivation of DS genes in human cancer, functional inactivation of the DS may predispose to invasiveness. An example for this hypothesis is the finding that conditional inactivation of Desmoplakin (DSP) in the Rip1Tag2 mouse model of pancreatic cancer resulted in increased local invasion of E-cadherin expressing tumor cells (Chun and Hanahan 2010), thus advocating the possibility that desmosomal inactivation may also precede late AJ inactivation in IDC and thereby promote tumor progression.

In conclusion, direct genetic inactivation of AJ components that are directly linked to actin remodeling is causal to tumor development and progression in ILC and HDGC, whereas late inactivation may control metastatic behavior in other tumor types like IDC. Likewise, inactivation of DS and TJ function is frequently observed, although the cause for inactivation remains elusive and their contribution to E-cadherin negative ILC harboring wild-type $\mathrm{CDH} 1$ alleles is unknown. Given that integrity and function of epithelial adhesion complexes heavily depend on their associated and neighboring complex members, it will be interesting to map and functionally validate inactivating 
H.C. Bruner and P.W.B. Derksen

mutations of AJ-associated complexes such as the TJ and DS to establish whether they contribute to the cancers that are driven by E-cadherin loss of function.

\section{BIOCHEMICAL CONSEQUENCES OF EARLY E-CADHERIN LOSS IN CANCER}

In the last decade a number of studies have addressed the biochemical and functional consequences of mutational E-cadherin inactivation in cancer. These studies showed that, despite the assumption by many that $\beta$-catenin would be uncoupled from the AJ on mutational inactivation of E-cadherin and subsequently contribute to canonical WNT signaling, this was shown not to be the case. Instead, it has become evident that E-cadherin inactivating mutations in cancer cells lead to low $\beta$-catenin expression without an increase in nuclear translocation and subsequent induction of TCF/LEF-dependent transcriptional activity (van de Wetering et al. 2001; Herzig et al. 2007; Schackmann et al. 2011). Unlike $\beta$-catenin, p120 is not degraded in human ILC, but instead accumulates in the cytoplasm and nucleus. Several lines of evidence have implicated an oncogenic function for p120. It has been well established that loss of E-cadherin leads to cytosolic translocation of p120 in a variety of different tumor types including breast, colon, lung, and gastric tumors (Thoreson and Reynolds 2002). Studies in breast and colon cancer indicate that cytosolic expression of p120 controls the invasive phenotype of E-cadherin negative cells (Bellovin 2005; Macpherson et al. 2007; Soto et al. 2008; Schackmann et al. 2011). In mouse and human ILC models, p120 translocates to the cytosol where it drives anchorageindependent survival and metastatic dissemination (Schackmann et al. 2011). Mechanistically, p120 controls anoikis resistance of E-cadherin mutant cells by indirect activation of Rho-associated kinase 1 (Rock1) through binding and inhibition of Rho antagonist myosin phosphatase Rho-interacting Protein (MRIP) (Schackmann et al. 2011) (see Fig. 2). In conjunction with the Rock-mediated effects, E-cadherin loss might also induce YAP/TAZ signals because Rock-mediated actomyosin contraction is strongly linked to YAP-induced proliferation through TEAD-dependent transcription (Wada et al. 2011; Aragona et al. 2013). Support for the assumption that loss of E-cadherin is associated with acquisition of YAP activity are findings that YAP controls cancer progression (Lamar et al. 2012; Chen et al. 2012) and that, IDC, ILC, and its precursor lesion, LCIS are characterized by nuclear YAP localization (Vlug et al. 2013b and E. Vlug, unpubl.). Interestingly, in the normal mammary gland only myoepithelial cells express nuclear YAP (Vlug et al. 2013b; Jaramillo-Rodriguez et al. 2014), suggesting that luminal ILC cells have obtained a distinct basal cellular feature that might enhance tumor progression.

In parallel, nuclear localization of p120 is increased approximately two-fold in anchorage-independent ILC cells, which leads to transcriptional derepression of the Kaiso target gene Wnt1 1 to drive autocrine Rho-Rock activity (van de Ven et al. 2015). This mechanism is essential to promote anoikis resistance of ILC cells (see Fig. 2). Interestingly, nuclear p120 acts as a rate limiting inhibitor of Kaiso in transcriptionally active regions, implying that Kaiso functions as a tumor suppressor in E-cadherin mutant cancer (van de Ven et al. 2015). Recently, a similar mechanism was proposed in the p120-dependent regulation of REST/CoREST-mediated transcriptional repression of genes involved in stem cell differentiation (Lee et al. 2014). Together, they suggest that nuclear p120 may have a broad function in the regulation of transcriptional derepression on E-cadherin loss in cancer.

In more basal-type breast cancers where Ecadherin is inactivated through epigenetic mechanisms, p120 is also translocated to the cytosol. In contrast to ILC however, MDAMB-231 cells (a triple negative and Claudin low IDC cell line) showed p120 binding to mesenchymal cadherins such as Cadherin-11, which controlled activation of Racl and RasMAPK signaling (Yanagisawa and Anastasiadis 2006; Soto et al. 2008). Similar findings have been obtained in Ras or Src-transformed MDCK cells (Dohn et al. 2009). These findings appear counterintuitive and might be cell-type specific, because Cadherin-11 is usually not localized the cytosolic compartment of the cell 
(Pishvaian et al. 1999). However, regardless of the cell type used, a common denominator in these studies was the acquisition of invasiveness and anchorage-independent growth. Given these characteristics, disseminating ILC cells may have developed autocrine biochemical cues that promote cellular survival ex situ, an assumption that is in line with the observations that cytosolic and nuclear translocation of p120 can drive distinct transcriptional programs (Kim et al. 2004; Lee et al. 2014). Based on the virtual absence of a canonical WNT signal in Ecadherin mutant cancer cells and the overlap between Kaiso and TCF/LEF targets (Park et al. 2005), the biological responses through p120/Kaiso- and $\beta$-catenin/TCF-dependent transcriptional activity may be mutually exclusive. As a consequence, specificity may have evolved to control homeostasis through differential regulation of a given gene in response to distinct proximal signals.

In conclusion, the net effect of translocated p120 in E-cadherin mutant cancer is the induction of anchorage-independence and migration through several mechanisms: first, it activates actomyosin contraction through indirect activation of Rock1; second, it binds and derepresses Kaiso to drive expression of distinct target genes like Wnt11 expression and subsequent autocrine RhoA activation; third, p120 controls Kaiso-independent transcriptional processes that may be beneficial for cancer progression (see Fig. 2B for an overview of the affected pathways). Based on the current literature, it appears that in E-cadherin negative cancers that are not caused by early mutational E-cadherin inactivation, p120 is also retained in the cytosol, but might control different tumor-promoting mechanisms caused by binding of mesenchymal-type cadherins (Yanagisawa and Anastasiadis 2006; Soto et al. 2008; Dohn et al. 2009).

\section{CLINICAL INTERVENTION OPTIONS AND FUTURE PERSPECTIVES}

Studies in human and mouse ILC have shown that E-cadherin inactivation leads to multidrug resistance, up-regulation of BCL2, and autocrine Wnt11-mediated activation of Rock-de- pendent anchorage-independent tumor growth and metastasis (reviewed in Christgen and Derksen 2015). Rock1 regulates the actomyosin-dependent contraction of the actin cytoskeleton and cellular metabolism through phosphorylation of downstream effectors such as Cofilin (Maekawa et al. 1999) and Myosin Light Chain (MLC) (Totsukawa et al. 2000). In cancer, activation or overexpression of Rho GTPases and downstream Rock signaling components correlate strongly with invasion, angiogenesis and overall aggressiveness of several tumors (Sahai and Marshall 2002). In vitro studies and animal models have suggested that inhibition of the Rho-Rock pathway may be a clinically relevant target in cancer. In a rat hepatoma model, genetic experiments showed that kinase inhibition of Rock reduces tumor cell invasiveness (Itoh et al. 1999). Furthermore, invasiveness of many cell lines can be decreased through the Rock inhibitors Y-27632 (Itoh et al. 1999; Wicki and Niggli 2001) and WF-536 (Nakajima et al. 2003). Preclinical usage of the clinically approved antivasoconstrictive drug Fasudil in mouse xenografting models of lung and breast cancer specifically inhibited invasiveness and metastasis, rather than cellular proliferation (Ying et al. 2006). In conclusion, pharmacological inhibition of Rock signaling can inhibit prometastatic traits in a cell-type specific manner and represents a prime candidate for clinical implementation to inhibit HDGC and ILC.

Despite the striking phenotypical and functional similarities between the current mouse and human ILC models, a clinical characteristic of most ILC cases is the expression of the estrogen receptor (ER) and accompanying responsiveness to ER antagonists such as tamoxifen and aromatase inhibitors (Sikora et al. 2013). Unfortunately, neither the human ILC cell line IPH-926 nor the mouse model systems express ER and are as such not satisfactory models for ER-positive ILC. Nonetheless, it is clear that ILC patients in general cannot successfully be treated using standard chemotherapy (Cristofanilli et al. 2005; Purushotham et al. 2010), resulting in a poor overall prognosis if endocrine treatment is unsuccessful. Given that the mouse and human ILC models are equally chemo-refractory 
to taxanes, platinum drugs and anthracyclines (J. Jonkers and P. Derksen, unpubl.), and the fact that their etiology is based on E-cadherindependent AJ function, they are valuable tools in identifying the downstream oncogenic effectors that are unleashed on early E-cadherin loss.

A key feature of E-cadherin mutant cancer cells is that they can survive under anchorageindependent conditions, a feature designated as anoikis resistance (Meredith et al. 1993; Frisch and Francis 1994). E-cadherin is causal in the acquisition of anchorage-independence because re-expression of E-cadherin in E-cadherin mutant cells leads to restoration of anoikis (Derksen et al. 2006). Interestingly, the literature has reported several ILC cases in which distant metastasis had developed without the presence of a detectable primary tumor mass (Engelstaedter and Mylonas 2011; Tomizawa et al. 2012), a phenotype that was also observed in the WAPcre-driven mouse models of human ILC (Derksen et al. 2011). Moreover, women suffering from ILC show a higher incidence in the development of clonally-related contralateral lesions (Newstead et al. 1992). Together, these data demonstrate that anoikis resistance is an intrinsic and cardinal feature of E-cadherin mutant cancers that provides the survival cue that controls anchorage independence during tumor cell dissemination.

What prevents E-cadherin mutant cells from undergoing anoikis? Mammary gland homeostasis depends on controlled spatiotemporal induction of anoikis in specific luminal epithelial cells that line the ductal structures, thus ensuring the formation of a hollow lumen (Humphreys et al. 1996; Debnath et al. 2002; Inman et al. 2015). In this homeostatic process, the $\mathrm{BH} 3$-only proapoptotic proteins BIM and $\mathrm{BMF}$ induce anoikis resulting in clearance of the central duct and subsequent formation of a tubular structure (Mailleux et al. 2007; Schmelzle et al. 2007). Although proapoptotic protein expression can be induced by multiple stimuli, including DNA damage, nutrient deprivation, heat and hypoxia (Strasser et al. 2011), BMF seems to preferentially induce anoikis in epithelial cells (Schmelzle et al. 2007; Hausmann et al. 2011). Proper anoikis control is lost early during the in situ stages of breast cancer, resulting in filling of the mammary duct with anoikis-resistant cells. This process can be triggered by activation of oncogenic growth factor receptor (GFR) signaling (Humphreys et al. 1996; Muthuswamy et al. 2001; Schmelzle et al. 2007). Because similar effects are triggered on inhibition of BIM, BMF, and p53 (Schmelzle et al. 2007; Mailleux et al. 2007; Danes et al. 2008), this indicates that either GFR activation and/ or the inhibition of distal proapoptotic effectors underlie anchorage independence of breast cancer cells. Corroborating this is the fact that mutations in PI3K are common in breast cancer (Desmedt et al. 2016; Fang et al. 2016) and that hyperactivation of PI3K and its downstream effector AKT/PKB can lead to anoikis resistance through phosphorylation-dependent inactivation of proapoptotic proteins like BAD and BIM (Datta et al. 1997; Schmelzle et al. 2007). Interestingly, E-cadherin homotypic adhesion inhibits GFR signaling (Qian et al. 2004) possibly through an NF2/Merlin dependent intracellular mechanism (Curto et al. 2007). Because Merlin can form a complex with E-cadherin to stabilize the AJ-actin association (Sainio et al. 1997; James et al. 2001; Curto et al. 2007), loss of E-cadherin may result in phosphorylation and unfolding of the closed Merlin configuration leading to decreased contact inhibition caused by increased GFR (Cole et al. 2008), Rac (Shaw et al. 2001), and YAP/TAZ signals (Jahanshahi et al. 2016) (reviewed in Petrilli and Fernández-Valle 2016)(see Fig. 2B).

Alternatively, cadherins might repress GFR activation through direct binding to neighboring growth factor receptors such as EGFR (Qian et al. 2004) or extracellular steric hindrance of growth factor presentation by heparin sulfate proteoglycans, an established mode of GFR attenuation in cancer (Derksen et al. 2004). Finally, AJs through regulation of TJs maintain a physical barrier, which could prevent growth factor receptors from reaching their ligands because of their difference in apical and basolateral membrane localization (Mellman and Nelson 2008). In cancer, experimental evidence for cadherin-dependent GFR repression was indirectly provided by showing that $\mathrm{AJ}$ dismantling 
on p120 knockout led to anchorage-independent tumor growth and metastasis caused by hypersensitization of endogenous GFR signaling (Schackmann et al. 2013). Moreover, in HDGC there is a correlation between increased EGFR activation and the presence of mutant Ecadherin (Bremm et al. 2008). In line with these findings it was recently shown that E-cadherin mutant cells specifically fail to transcriptionally up-regulate BMF because of AKT-dependent repression of FOXO3 (Hornsveld et al. 2016). Since extensive work by the Brugge laboratory has established that BIM may play similar roles in breast cancer through integrin and GFR signaling-dependent cues (Reginato et al. 2003), it appears that aberrant control of the proapoptotic $\mathrm{BH} 3$-only proteins is a key distal event in E-cadherin mutant cancer. As such, it might represent a clinical Achilles heel in the management of metastatic (H)DGC and ILC. Supporting this reasoning is the finding that preclinical treatment using $\mathrm{BH} 3$-only mimetics combined with chemotherapy or endocrine treatment regimens could successfully inhibit ER-positive breast cancer (Oakes et al. 2012; Vaillant et al. 2013).

This wealth of experimental data may have important clinical ramifications through the use of antibody-based or small molecule regimens that specifically inhibit GFR signaling, especially because hyperactivation of GFR signals in Ecadherin mutant cells appears to be instigated independent of somatic mutations that activate PI3K/AKT signals (M. Tenhagen, unpubl.). However, it appears that using proximal inhibition of GFR (e.g., targeting the ErbB1/2 receptors) in cancer is not the preferable strategy, because this treatment option is plagued by tumor relapses caused by unsuccessful debulking (tumor cell ablation through chemo or targeted anticancer therapies) and subsequent selection of resistant clones (Diaz et al. 2012; Gagliato et al. 2016). For cancers driven by E-cadherin loss, the preferable intervention strategy would then be to either focus on inhibitors of the more downstream AKT hub and combine them with activation of the most distal antitumor event or the induction of apoptosis through inhibition of proapoptotic BCL molecules. Although their clinical usage is currently limited to lymphoid malignancies, the BH3-only mimetics hold promise as an alternative or complementary treatment to specifically kill disseminating Ecadherin mutant cancer cells.

\section{CONCLUDING REMARKS}

Early mutational somatic or germline inactivation of E-cadherin leads to the development and progression of distinct cancer types in the breast and/or stomach. In the absence of functional redundancy by other classical cadherins, this results in loss of cell-cell adhesion and anchorage-independence, features that underpin the classical and typical invasive growth and cellular phenotype of the resulting HDGC and ILC tumor types. Based on the available evidence, it appears that early E-cadherin loss induces activation of two distinct oncogenic signals; first and foremost, constitutive Rock-dependent actomyosin activation and subsequent anchorage independence is induced by cytosolic p120; second, E-cadherin loss leads to hypersensitization of GFR signals, which attenuates FOXO-dependent transcriptional repression of the key proapoptotic players BMF and BIM (see Fig. 3). In addition, distinct transcriptional programs that might underlie E-cadherin deficient tumor etiology are instigated by transcriptional p120/ Kaiso derepression, activation of YAP/TAZ and probably other, currently unidentified transcriptional programs.

Because loss of the actin linker $\alpha$-catenin can, in principle, also initiate a classical E-cadherin-deficient cancer phenotype (in contrast to loss of p120) and most evidence points toward activation of actomyosin contraction by Rho/Rock, YAP/TAZ, and NF2/Merlin, we propose that E-cadherin mutant cancers like HDGC and ILC should be considered "actin" diseases. We think this term covers the essence of these diseases because they are primarily driven by linkage loss between the AJ and the actin cytoskeleton and a subsequent propagation of, and dependency on, constitutive actomyosin contractility. Moreover, the identification of inactivating CTNNA1 mutations in HDGC or ILC patients suggests that, in princi- 


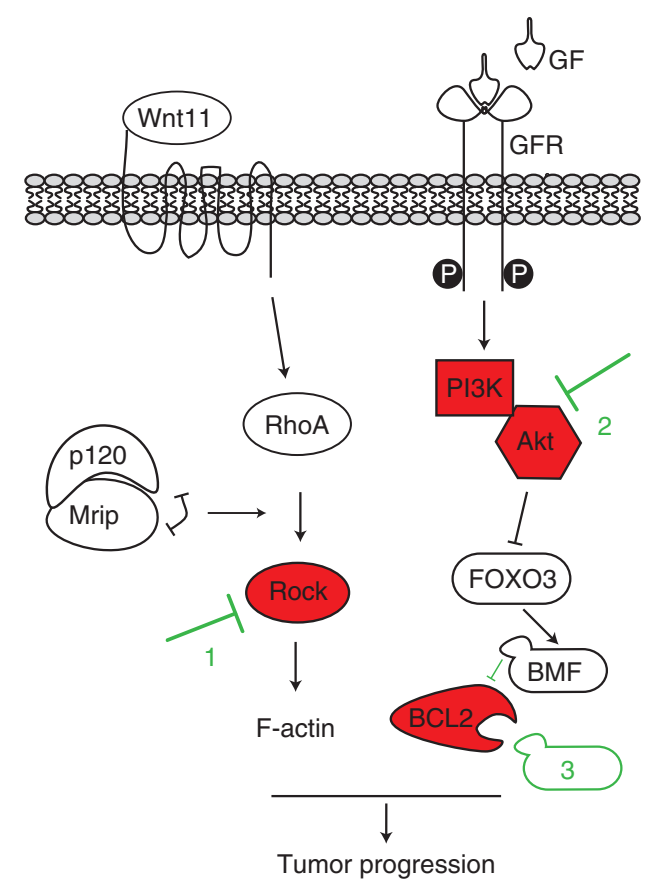

Figure 3. Options for clinical intervention of cancers driven by early E-cadherin loss. ILC tumor growth and metastasis are driven by p120-dependent activation of Rock and hyperactivation of GFR signaling on E-cadherin inactivation (as outlined in Fig. 2B). As a result, PI3K/AKT signals will inhibit FOXO3-mediated BMF transcription and prevent programmed cell death in the absence of anchorage. Clinical intervention should therefore focus on inhibition of Rock, $\mathrm{PI} 3 \mathrm{~K} / \mathrm{AKT}$, and BCL2 using BH3-only mimetics. Combining these targeted treatments with standard chemotherapy and/or endocrine drugs to inhibited estrogen receptor (ER) function, might be beneficial in cancers driven by early E-cadherin loss, such as (hereditary) diffuse gastric cancer (HDGC) and invasive lobular breast cancer (ILC).

pal, any mutation that functionally results in an "E-cadherin-type" actin deregulation, might underpin the development of these cancers. In line with this rationale we hypothesize that (similar to E-cadherin or $\alpha$-catenin loss), aberrant control or loss of distinct desmosomal or TJ molecules at the initiating stages of cancer development might cause deregulation of AJdependent cell-cell adhesion and actomyosin contraction, leading to HDGC or ILC. It is currently unclear whether activation of Rock- dependent actomyosin contraction acts in parallel to or operates in conjunction with GFR-dependent activation of PI3K/AKT and the repression of BIM/BMF. Notwithstanding this we feel that from a clinical point of view the current scientific evidence paves the way for targeted intervention of cancers like HDGC and ILC using inhibitors of Rock, AKT, and BCL2 (the BH3-only mimetics), alone or in combination with standard endocrine or chemotherapy regimens (see Fig. 3 for an overview).

\section{ACKNOWLEDGMENTS}

We would like to thank Dana Pirone and Johan de Rooij for critically reading this manuscript. The Derksen and van Diest laboratories are acknowledged for support and suggestions. This Research was supported by grants from the Netherlands Organization for Scientific Research (NWO/ZonMW-VIDI 016.096.318), Foundation Vrienden UMC Utrecht (11.081), the Dutch Cancer Society (KWF-UU-20115230, KWF-UU-2014-7201, and KWF-UU2016-10456) and H2020-FETPROACT/20162017/731957.

\section{REFERENCES}

Agiostratidou G, Li M, Suyama K, Badano I, Keren R, Chung S, Anzovino A, Hulit J, Qian B, Bouzahzah B, et al. 2009. Loss of retinal cadherin facilitates mammary tumor progression and metastasis. Cancer Res 69: 5030-5038.

Akai T, Nabeya Y, Yahiro K, Morinaga N, Mitsuhashi K, Inoue M, Sakamoto A, Ochiai T, Noda M. 2006. Helicobacter pylori induces mono-(adenosine 5'-diphosphate)ribosylation in human gastric adenocarcinoma. Int J Oncol 29: 965-972.

Albergaria A, Ribeiro AS, Vieira A-F, Sousa B, Nobre A-R, Seruca R, Schmitt F, Paredes J. 2011. P-cadherin role in normal breast development and cancer. Int J Dev Biol 55: 811-822.

Andreu P, Colnot S, Godard C, Laurent-Puig P, Lamarque D, Kahn A, Perret C, Romagnolo B. 2006. Identification of the IFITM family as a new molecular marker in human colorectal tumors. Cancer Res 66: 1949-1955.

Annunziato S, Kas SM, Nethe M, Yücel H, Del Bravo J, Pritchard C, Bin Ali R, van Gerwen B, Siteur B, Drenth AP, et al. 2016. Modeling invasive lobular breast carcinoma by CRISPR/Cas9-mediated somatic genome editing of the mammary gland. Genes Dev 30: 1470-1480. 
Aragona M, Panciera T, Manfrin A, Giulitti S, Michielin F, Elvassore N, Dont S, Piccolo S. 2013. A mechanical checkpoint controls multicellular growth through YAP/ TAZ regulation by actin-processing factors. Cell 154: 1047-1059.

Becker KF, Atkinson MJ, Reich U, Becker I, Nekarda H, Siewert JR, Hofler H. 1994. E-cadherin gene mutations provide clues to diffuse type gastric carcinomas. Cancer Res 54: 3845-3852.

Behrens J, Birchmeier W, Goodman SL, Imhof BA. 1985. Dissociation of Madin-Darby canine kidney epithelial cells by the monoclonal antibody anti-arc-1: Mechanistic aspects and identification of the antigen as a component related to uvomorulin. J Cell Biol 101: 1307-1315.

Behrens J, Mareel MM, Van Roy FM, Birchmeier W. 1989. Dissecting tumor cell invasion: Epithelial cells acquire invasive properties after the loss of uvomorulin-mediated cell-cell adhesion. J Cell Biol 108: 2435-2447.

Bellovin DI. 2005. Altered Localization of p120 Catenin during epithelial to mesenchymal transition of colon carcinoma is prognostic for aggressive disease. Cancer Res 65: 10938-10945.

Berx G, Van Roy F. 2009. Involvement of members of the cadherin superfamily in cancer. Cold Spring Harb Perspect Biol 1: a003129.

Berx G, Cleton-Jansen AM, Nollet F, de Leeuw WJ, van de Vijver M, Cornelisse C, Van Roy F. 1995. E-cadherin is a tumour/invasion suppressor gene mutated in human lobular breast cancers. EMBO J 14: 6107-6115.

Berx G, Cleton-Jansen AM, Strumane K, de Leeuw WJ, Nollet F, Van Roy F, Cornelisse C. 1996. E-cadherin is inactivated in a majority of invasive human lobular breast cancers by truncation mutations throughout its extracellular domain. Oncogene 13: 1919-1925.

Berx G, Becker KF, Hofler H, Van Roy F. 1998. Mutations of the human E-cadherin (CDH1) gene. Hum Mutat 12: 226-237.

Boussadia O, Kutsch S, Hierholzer A, Delmas V, Kemler R. 2002. E-cadherin is a survival factor for the lactating mouse mammary gland. Mech Dev 115: 53-62.

Bremm A, Walch A, Fuchs M, Mages J, Duyster J, Keller G, Hermannstädter C, Becker K-F, Rauser S, Langer R, et al. 2008. Enhanced activation of epidermal growth factor receptor caused by tumor-derived E-cadherin mutations. Cancer Res 68: 707-714.

Brennan D, Mahoney MG. 2009. Increased expression of Dsg2 in malignant skin carcinomas: A tissue-microarray based study. Cell Adh Migr 3: 148-154.

Butz S, Stappert J, Weissig H, Kemler R. 1992. Plakoglobin and $\beta$-catenin: distinct but closely related. Science 257: $1142-1144$.

Canas-Marques R, Schnitt SJ. 2015. E-cadherin immunohistochemistry in breast pathology: uses and pitfalls. Histopathology 68: 57-69.

Chen YJ, Chang JT, Lee L, Wang HM, Liao CT, Chiu CC, Chen PJ, Cheng AJ. 2007. DSG3 is overexpressed in head neck cancer and is a potential molecular target for inhibition of oncogenesis. Oncogene 26: 467-476.

Chen D, Sun Y, Wei Y, Zhang P, Rezaeian AH, Teruya-Feldstein J, Gupta S, Liang H, Lin H-K, Hung MC, et al. 2012. LIFR is a breast cancer metastasis suppressor upstream of the Hippo-YAP pathway and a prognostic marker. Nat Med 1-9.

Chen QK, Lee K, Radisky DC, Nelson CM. 2013. Extracellular matrix proteins regulate epithelial-mesenchymal transition in mammary epithelial cells. Differentiation 86: $126-132$.

Cheung KJ, Gabrielson E, Werb Z, Ewald AJ. 2013. Collective invasion in breast cancer requires a conserved Basal epithelial program. Cell 155: 1639-1651.

Christgen M, Derksen PW. 2015. Lobular breast cancer: Molecular basis, mouse and cellular models. 17: 491.

Chun MG, Hanahan D. 2010. Genetic deletion of the desmosomal component desmoplakin promotes tumor microinvasion in a mouse model of pancreatic neuroendocrine carcinogenesis. PLoS Genet 6.

Cole BK, Curto M, Chan AW, McClatchey AI. 2008. Localization to the cortical cytoskeleton is necessary for Nf2/ merlin-dependent epidermal growth factor receptor silencing. Mol Cell Biol 28: 1274-1284.

Cool M, Jolicoeur P. 1999. Elevated frequency of loss of heterozygosity in mammary tumors arising in mouse mammary tumor virus/neu transgenic mice. Cancer Res 59: 2438-2444.

Cristofanilli M, Gonzalez-Angulo A, Sneige N, Kau S, Broglio K, Theriault R, Valero V, Buzdar A, Kuerer H, Buccholz T, et al. 2005. Invasive lobular carcinoma classic type: Response to primary chemotherapy and survival outcomes. J Clin Oncol 23: 41-48.

Curto M, Cole BK, Lallemand D, Liu C-H, McClatchey AI. 2007. Contact-dependent inhibition of EGFR signaling by Nf2/Merlin. J Cell Biol 177: 893-903.

Dabbs DJ, Bhargava R, Chivukula M. 2007. Lobular versus ductal breast neoplasms: The diagnostic utility of p120 catenin. Am J Surg Pathol 31: 427-437.

Dahl U, Sjødin A, Semb H. 1996. Cadherins regulate aggregation of pancreatic $\beta$-cells in vivo. Development 122: 2895-2902.

Danes CG, Wyszomierski SL, Lu J, Neal CL, Yang W, Yu D. 2008. 14-3-3 $\zeta$ down-regulates p53 in mammary epithelial cells and confers luminal filling. Cancer Res 68: 17601767.

Daniel CW, Strickland P, Friedmann Y. 1995. Expression and functional role of E- and P-cadherins in mouse mammary ductal morphogenesis and growth. Dev Biol 169: 511519.

Datta SR, Dudek H, Tao X, Masters S, Fu H, Gotoh Y, Greenberg ME. 1997. Akt phosphorylation of BAD couples survival signals to the cell-intrinsic death machinery. Cell 91: 231-241.

Davis MA, Ireton RC, Reynolds AB. 2003. A core function for p120-catenin in cadherin turnover. J Cell Biol 163: 525-534.

De Craene B, Berx G. 2013. Regulatory networks defining EMT during cancer initiation and progression. Nat Rev Cancer 13: 97-110.

Debnath J, Mills KR, Collins NL, Reginato MJ, Muthuswamy SK, Brugge JS. 2002. The role of apoptosis in creating and maintaining luminal space within normal and oncogene-expressing mammary acini. Cell 111:29-40.

Delva E, Tucker DK, Kowalczyk AP. 2009. The desmosome. Cold Spring Harb Perspect Biol 1: a002543. 
Derksen PWB, Tjin E, Meijer HP, Klok MD, MacGillavry HD, van Oers MHJ, Lokhorst HM, Bloem AC, Clevers H, Nusse R, et al. 2004. Illegitimate WNT signaling promotes proliferation of multiple myeloma cells. Proc Natl Acad Sci 101: 6122-6127.

Derksen PWB, Liu X, Saridin F, Van Der Gulden H, Zevenhoven J, Evers B, van Beijnum JR, Griffioen AW, Vink J, Krimpenfort P, et al. 2006. Somatic inactivation of Ecadherin and p53 in mice leads to metastatic lobular mammary carcinoma through induction of anoikis resistance and angiogenesis. Cancer Cell 10: 437-449.

Derksen PWB, Braumuller TM, Van Der Burg E, Hornsveld M, Mesman E, Wesseling J, Krimpenfort P, Jonkers J. 2011. Mammary-specific inactivation of E-cadherin and p53 impairs functional gland development and leads to pleomorphic invasive lobular carcinoma in mice. Dis Model Mech 4: 347-358.

Desmedt C, Zoppoli G, Gundem G, Pruneri G, Larsimont D, Fornili M, Fumagalli D, Brown D, Rothé F, Vincent D, et al. 2016. Genomic characterization of primary invasive lobular breast cancer. J Clin Oncol 34: 1872-1881.

Di-Cicco A, Petit V, Chiche A, Bresson L, Romagnoli M, Orian-Rousseau V, Vivanco MD, Medina D, Faraldo MM, Glukhova MA, et al. 2015. Paracrine Met signaling triggers epithelial-mesenchymal transition in mammary luminal progenitors, affecting their fate. eLife 4: e06104.

Diaz LA, Williams RT, Wu J, Kinde I, Hecht JR, Berlin J, Allen B, Bozic I, Reiter JG, Nowak MA, et al. 2012. The molecular evolution of acquired resistance to targeted EGFR blockade in colorectal cancers. Nature 486: 537 540.

Diepenbruck M, Christofori G. 2016. Epithelial-mesenchymal transition (EMT) and metastasis: Yes, no, maybe? Curr Opin Cell Biol 43: 7-13.

Dohn MR, Brown MV, Reynolds AB. 2009. An essential role for p120-catenin in Src- and Rac1-mediated anchorageindependent cell growth. J Cell Biol 184: 437-450.

Dusek RL, Attardi LD. 2011. Desmosomes: New perpetrators in tumour suppression. Nat Rev Cancer 11:317-323.

Engelstaedter V, Mylonas I. 2011. Lower genital tract metastases at time of first diagnosis of mammary invasive lobular carcinoma. Arch Gynecol Obstet 283: 93-95.

Fang WL, Huang KH, Lan YT, Lin CH, Chang SC, Chen MH, Chao Y, Lin WC, Lo SS, Li AFY, et al. 2016. Mutations in PI3K/AKT pathway genes and amplifications of PIK3CA are associated with patterns of recurrence in gastric cancers. Oncotarget 7: 6201-6220.

Frisch SM, Francis H. 1994. Disruption of epithelial cellmatrix interactions induces apoptosis. J Cell Biol 124: 619-626.

Furukawa C, Daigo Y, Ishikawa N, Kato T, Ito T, Tsuchiya E, Sone S, Nakamura Y. 2005. Plakophilin 3 oncogene as prognostic marker and therapeutic target for lung cancer. Cancer Res 65: 7102-7110.

Furuse M. 2010. Molecular basis of the core structure of tight junctions. Cold Spring Harb Perspect Biol 2: a002907.

Gagliato D de M, Jardim DLF, Marchesi MSP, Hortobagyi GN. 2016. Mechanisms of resistance and sensitivity to anti-HER2 therapies in HER2 + breast cancer. Oncotarget 5 .
Guilford P, Hopkins J, Harraway J, McLeod M, McLeod N, Harawira P, Taite H, Scoular R, Miller A, Reeve AE. 1998. E-cadherin germline mutations in familial gastric cancer. Nature 392: 402-405.

Hatzfeld M, Nachtsheim C. 1996. Cloning and characterization of a new armadillo family member, p0071, associated with the junctional plaque: Evidence for a subfamily of closely related proteins. J Cell Sci 109: 2767-2778.

Hausmann M, Leucht K, Ploner C, Kiessling S, Villunger A, Becker H, Hofmann C, Falk W, Krebs M, Kellermeier S, et al. 2011. BCL-2 modifying factor (BMF) is a central regulator of anoikis in human intestinal epithelial cells. J Biol Chem 286: 26533-26540.

Hazan RB, Kang L, Roe S, Borgen PI, Rimm DL. 1997a. Vinculin is associated with the E-cadherin adhesion complex. J Biol Chem 272: 32448-32453.

Hazan RB, Kang L, Whooley BP, Borgen PI. 1997b. N-cadherin promotes adhesion between invasive breast cancer cells and the stroma. Cell Adhes Commun 4: 399-411.

Hazan RB, Qiao R, Keren R, Badano I, Suyama K. 2004. Cadherin switch in tumor progression. Ann N Y Acad Sci 1014: 155-163.

Herzig M, Savarese F, Novatchkova M, Semb H, Christofori G. 2007. Tumor progression induced by the loss of Ecadherin independent of $\beta$-catenin/Tcf-mediated Wnt signaling. Oncogene 26: 2290-2298.

Hollestelle A, Elstrodt F, Timmermans M, Sieuwerts AM, Klijn JGM, Foekens JA, Bakker MA, Schutte M. 2010. Four human breast cancer cell lines with biallelic inactivating $\alpha$-catenin gene mutations. Breast Cancer Res Treat 122: $125-133$.

Hoover KB, Liao SY, Bryant PJ. 1998. Loss of the tight junction MAGUK ZO-1 in breast cancer: relationship to glandular differentiation and loss of heterozygosity. Am J Pathol 153: 1767-1773.

Hornsveld M, Tenhagen M, van de Ven RA, Smits AMM, van Triest MH, van Amersfoort M, Kloet DEA, Dansen TB, Burgering BM, Derksen PWB. 2016. Restraining FOXO3-dependent transcriptional BMF activation underpins tumour growth and metastasis of E-cadherinnegative breast cancer. Cell Death Differ.

Humphreys RC, Krajewska M, Krnacik S, Jaeger R, Weiher H, Krajewski S, Reed JC, Rosen JM. 1996. Apoptosis in the terminal endbud of the murine mammary gland: a mechanism of ductal morphogenesis. Development 122: 4013-4022.

Inman JL, Robertson C, Mott JD, Bissell MJ. 2015. Mammary gland development: cell fate specification, stem cells and the microenvironment. Development 142: $1028-1042$.

Ireton RC, Davis MA, van Hengel J, Mariner DJ, Barnes K, Thoreson MA, Anastasiadis PZ, Matrisian L, Bundy LM, Sealy L, et al. 2002. A novel role for p120 catenin in Ecadherin function. J Cell Biol 159: 465-476.

Islam S, Carey TE, Wolf GT, Wheelock MJ, Johnson KR. 1996. Expression of N-cadherin by human squamous carcinoma cells induces a scattered fibroblastic phenotype with disrupted cell-cell adhesion. J Cell Biol 135: $1643-1654$.

Itoh K, Yoshioka K, Akedo H, Uehata M, Ishizaki T, Narumiya S. 1999. An essential part for $\rho$-associated kinase in 
the transcellular invasion of tumor cells. Nat Med 5:221225.

Jahanshahi M, Hsiao K, Jenny A, Pfleger CM. 2016. The Hippo pathway targets Rael to Regulate mitosis and organ size and to feed back to regulate upstream components Merlin, Hippo, and Warts. PLoS Genet 12: e1006198.

James MF, Manchanda N, Gonzalez-Agosti C, Hartwig JH, Ramesh V. 2001. The neurofibromatosis 2 protein product merlin selectively binds F-actin but not G-actin, and stabilizes the filaments through a lateral association. Biochem J 356: 377-386.

Jaramillo-Rodríguez Y, Cerda-Flores RM, Ruiz-Ramos R, López-Márquez FC, Calderón-Garcidueñas AL. 2014 YAP expression in normal and neoplastic breast tissue: An immunohistochemical study. Arch Med Res 45: 223 228.

Kalluri R, Weinberg RA. 2009. The basics of epithelial-mesenchymal transition. J Clin Invest 119: 1420-1428.

Kaurah P, MacMillan A, Boyd N, Senz J, De Luca A, Chun N, Suriano G, Zaor S, Van Manen L, Gilpin C, et al. 2007. Founder and recurrent $\mathrm{CDH} 1$ mutations in families with hereditary diffuse gastric cancer. JAMA 297: 2360-2372.

Kim SW, Park J-I, Spring CM, Sater AK, Ji H, Otchere AA, Daniel JM, Mccrea PD. 2004. Non-canonical Wnt signals are modulated by the Kaiso transcriptional repressor and p120-catenin. Nat Cell Biol 6: 1212-1220.

Klus GT, Rokaeus N, Bittner ML, Chen Y, Korz DM, Sukumar S, Schick A, Szallasi Z. 2001. Down-regulation of the desmosomal cadherin desmocollin 3 in human breast cancer. Int J Oncol 19: 169-174.

Kominsky SL, Argani P, Korz D, Evron E, Raman V, Garrett E, Rein A, Sauter G, Kallioniemi OP, Sukumar S. 2003. Loss of the tight junction protein claudin-7 correlates with histological grade in both ductal carcinoma in situ and invasive ductal carcinoma of the breast. Oncogene 22: 2021-2033.

Kurley SJ, Bierie B, Carnahan RH, Lobdell NA, Davis MA, Hofmann I, Moses HL, Muller WJ, Reynolds AB. 2012. p120-catenin is essential for terminal end bud function and mammary morphogenesis. Development 139(10): 1754-1764.

Lamar JM, Stern P, Liu H, Schindler JW, Jiang Z-G, Hynes RO. 2012. The Hippo pathway target, YAP, promotes metastasis through its TEAD-interaction domain. Proc Natl Acad Sci 109: E2441-50.

Larue L, Ohsugi M, Hirchenhain J, Kemler R. 1994. E-cadherin null mutant embryos fail to form a trophectoderm epithelium. Proc Natl Acad Sci 91: 8263-8267.

Leckband DE, de Rooij J. 2014. Cadherin adhesion and mechanotransduction. Annu Rev Cell Dev Biol 30: 291 315.

Lecuit T, Yap AS. 2015. E-cadherin junctions as active mechanical integrators in tissue dynamics. Nat Cell Biol 17: 533-539.

Lee M, Ji H, Furuta Y, Park J-I, Mccrea PD. 2014. P120catenin regulates REST/CoREST, and modulates mouse embryonic stem cell differentiation. J Cell Sci 151944.

Liu X, Holstege H, van der G, Treur-Mulder M, Zevenhoven J, Velds A, Kerkhoven R, van Vliet M, Wessels L, Peterse J, et al. 2007. Somatic loss of BRCA1 and p53 in mice in- duces mammary tumors with features of human BRCA1mutated basal-like breast cancer. Proc Natl Acad Sci 104: 12111-12116.

Macpherson IR, Hooper S, Serrels A, Mcgarry L, Ozanne BW, Harrington K, Frame MC, Sahai E, Brunton VG. 2007. p120-catenin is required for the collective invasion of squamous cell carcinoma cells via a phosphorylationindependent mechanism. Oncogene 26: 5214-5228.

Maekawa M, Ishizaki T, Boku S, Watanabe N, Fujita A, Iwamatsu A, Obinata T, Ohashi K, Mizuno K, Narumiya S. 1999. Signaling from $\rho$ to the actin cytoskeleton through protein kinases ROCK and LIM-kinase. Science.

Mahmud N, Ford JM, Longacre TA, Parent R, Norton JA. 2015. Metastatic lobular breast carcinoma mimicking primary signet ring adenocarcinoma in a patient with a suspected CDH1 mutation. J Clin Oncol 33: e19-21.

Mailleux AA, Overholtzer M, Schmelzle T, Bouillet P, Strasser A, Brugge JS. 2007. BIM regulates apoptosis during mammary ductal morphogenesis, and its absence reveals alternative cell death mechanisms. Dev Cell 12: 221-234.

Majewski IJ, Kluijt I, Cats A, Scerri TS, de Jong D, Kluin RJC, Hansford S, Hogervorst FBL, Bosma AJ, Hofland I, et al. 2013. An $\alpha$-E-catenin (CTNNA1) mutation in hereditary diffuse gastric cancer. J Pathol 229: 621-629.

Martin TA. 2014. The role of tight junctions in cancer metastasis. Semin Cell Dev Biol 36: 224-231.

Masciari S, Larsson N, Senz J, Boyd N, Kaurah P, Kandel MJ, Harris LN, Pinheiro HC, Troussard A, Miron P, et al. 2007. Germline E-cadherin mutations in familial lobular breast cancer. J Med Genet 44: 726-731.

McCaffrey LM, Montalbano J, Mihai C, Macara IG. 2012. Loss of the Par3 polarity protein promotes breast tumorigenesis and metastasis. Cancer Cell 22: 601-614.

McCrea PD, Turck CW, Gumbiner B. 1991. A homolog of the armadillo protein in Drosophila (plakoglobin) associated with E-cadherin. Science 254: 1359-1361.

Mellman I, Nelson WJ. 2008. Coordinated protein sorting, targeting and distribution in polarized cells. Nat Rev Mol Cell Biol 9: 833-845.

Meng W, Takeichi M. 2009. Adherens junction: Molecular architecture and regulation. Cold Spring Harb Perspect Biol 1: a002899.

Meredith JE, Fazeli B, Schwartz MA. 1993. The extracellular matrix as a cell survival factor. Mol Biol Cell 4: 953-961.

Moftah H, Dias K, Apu EH, Liu L, Uttagomol J, Bergmeier L, Kermorgant S, Wan H. 2016. Desmoglein 3 regulates membrane trafficking of cadherins, an implication in cell-cell adhesion. Cell Adh Migr 1-22.

Moll R, Mitze M, Frixen UH, Birchmeier W. 1993. Differential loss of E-cadherin expression in infiltrating ductal and lobular breast carcinomas. Am J Pathol 143: 17311742.

Molland J, Donnellan M, Janu N, Carmalt H, Kennedy C, Gillett D. 2004. Infiltrating lobular carcinoma--a comparison of diagnosis, management and outcome with infiltrating duct carcinoma. Breast 13: 389-396.

Muta H, Noguchi M, Kanai Y, Ochiai A, Nawata H, Hirohashi S. 1996. E-cadherin gene mutations in signet ring cell carcinoma of the stomach. Jpn J Cancer Res 87: 843-848. 
H.C. Bruner and P.W.B. Derksen

Muthuswamy SK, Li D, Lelievre S, Bissell MJ, Brugge JS. 2001. ErbB2, but not ErbB1, reinitiates proliferation and induces luminal repopulation in epithelial acini. Nat Cell Biol 3: 785-792.

Nagafuchi A, Shirayoshi Y, Okazaki K, Yasuda K, Takeichi M 1987. Transformation of cell adhesion properties by exogenously introduced E-cadherin cDNA. Nature 329: 341-343.

Nakajima M, Hayashi K, Egi Y, Katayama K-I, Amano Y, Uehata M, Ohtsuki M, Fujii A, Oshita K-I, Kataoka H, et al. 2003. Effect of Wf-536, a novel ROCK inhibitor, against metastasis of B16 melanoma. Cancer Chemother Pharmacol 52: 319-324.

Nanes BA, Chiasson-MacKenzie C, Lowery AM, Ishiyama N, Faundez V, Ikura M, Vincent PA, Kowalczyk AP. 2012. p120-catenin binding masks an endocytic signal conserved in classical cadherins. J Cell Biol 199: 365-380.

Newstead GM, Baute PB, Toth HK. 1992. Invasive lobular and ductal carcinoma: Mammographic findings and stage at diagnosis. Radiology 184: 623-627.

Nieto MA, Cano A. 2012. The epithelial-mesenchymal transition under control: Global programs to regulate epithelial plasticity. Semin Cancer Biol 22: 361-368.

Nieto MA, Huang RYJ, Jackson RA, Thiery JP. 2016. EMT: 2016. Cell 166: 21-45.

Nollet F, Kools P, Van Roy F. 2000. Phylogenetic analysis of the cadherin superfamily allows identification of six major subfamilies besides several solitary members. J Mol Biol 299: 551-572.

Oakes SR, Vaillant F, Lim E, Lee L, Breslin K, Feleppa F, Deb S, Ritchie ME, Takano E, Ward T, et al. 2012. Sensitization of BCL-2-expressing breast tumors to chemotherapy by the BH3 mimetic ABT-737. Proc Natl Acad Sci 109: 2766-2771.

Oliveira C, Seruca R, Carneiro F. 2006. Genetics, pathology, and clinics of familial gastric cancer. Int J Surg Pathol 14: $21-33$.

Oshiro MM, Kim CJ, Wozniak RJ, Junk DJ, Munoz-Rodriguez JL, Burr JA, Fitzgerald M, Pawar SC, Cress AE, Domann FE, et al. 2005. Epigenetic silencing of DSC3 is a common event in human breast cancer. Breast Cancer Res 7: R669-80.

Ozawa M, Engel J, Kemler R. 1990. Single amino acid substitutions in one $\mathrm{Ca}^{2+}$ binding site of uvomorulin abolish the adhesive function. Cell 63: 1033-1038.

Paredes J, Stove C, Stove V, Milanezi F, Van Marck V, Derycke L, Mareel M, Bracke M, Schmitt F. 2004. P-cadherin is upregulated by the antiestrogen ICI 182,780 and promotes invasion of human breast cancer cells. Cancer Res 64: 8309-8317.

Park J, Kim S, Lyons J, Ji H, Nguyen T, Cho K, Barton M, Deroo T, Vleminckx K, Moon R, et al. 2005. Kaiso/p120catenin and TCF $/ \beta$-catenin complexes coordinately regulate canonical Wnt gene targets. Dev Cell 8: 843-854.

Peralta Soler A, Knudsen KA, Salazar H, Han AC, Keshgegian AA. 1999. P-cadherin expression in breast carcinoma indicates poor survival. Cancer 86: 1263-1272.

Perez-Moreno M, Song W, Pasolli HA, Williams SE, Fuchs E. 2008. Loss of p120 catenin and links to mitotic alterations, inflammation, and skin cancer. Proc Natl Acad Sci 105: 15399-15404.
Perl A, Wilgenbus P, Dahl U, Semb H, Christofori G. 1998. A causal role for E-cadherin in the transition from adenoma to carcinoma. Nature 392: 190-193.

Petridis C, Shinomiya I, Kohut K, Gorman P, Caneppele M, Shah V, Troy M, Pinder SE, Hanby A, Tomlinson I, et al. 2014. Germline CDH1 mutations in bilateral lobular carcinoma in situ. Br J Cancer 110: 1053-1057.

Petrilli AM, Fernández-Valle C. 2016. Role of Merlin/NF2 inactivation in tumor biology. Oncogene 35: 537-548.

Pishvaian MJ, Feltes CM, Thompson P, Bussemakers MJ, Schalken JA, Byers SW. 1999. Cadherin-11 is Expressed in Invasive Breast Cancer Cell Lines. Cancer Res 59: 947.

Purushotham A, Pinder S, Cariati M, Harries M, Goldhirsch A. 2010. Neoadjuvant chemotherapy: not the best option in estrogen receptor-positive, HER2-negative, invasive classical lobular carcinoma of the breast? J Clin Oncol 28: 3552-3554.

Qian X, Karpova T, Sheppard AM, McNally J, Lowy DR. 2004. E-cadherin-mediated adhesion inhibits ligand-dependent activation of diverse receptor tyrosine kinases. EMBO J 23: 1739-1748.

Radice G, Ferreira-Cornwell M, Robinson S, Rayburn H, Chodosh L, Takeichi M, Hynes R. 1997. Precocious mammary gland development in P-cadherin-deficient mice. J Cell Biol 139: 1025-1032.

Rakha EA, Patel A, Powe DG, Benhasouna A, Green AR, Lambros MB, Reis-Filho JS, Ellis IO. 2010. Clinical and biological significance of E-cadherin protein expression in invasive lobular carcinoma of the breast. Am J Surg Pathol 34: 1472-1479.

Regan J, Smalley M. 2007. Prospective isolation and functional analysis of stem and differentiated cells from the mouse mammary gland. Stem Cell Rev 3: 124-136.

Reginato MJ, Mills KR, Paulus JK, Lynch DK, Sgroi DC, Debnath J, Muthuswamy SK, Brugge JS. 2003. Integrins and EGFR coordinately regulate the pro-apoptotic protein Bim to prevent anoikis. Nat Cell Biol 5: 733-740.

Reynolds A, Roesel D, Kanner S, Parsons J. 1989. Transformation-specific tyrosine phosphorylation of a novel cellular protein in chicken cells expressing oncogenic variants of the avian cellular src gene. Mol Cell Biol 9: 629-638.

Reynolds A, Daniel J, McCrea P, Wheelock M, Wu J, Zhang Z. 1994. Identification of a new catenin: the tyrosine kinase substrate $\mathrm{p} 120$ cas associates with E-cadherin complexes. Mol Cell Biol 14: 8333-8342.

Sahai E, Marshall CJ. 2002. $\rho$-GTPASES and cancer. Nat Rev Cancer 2: 133-142.

Sainio M, Zhao F, Heiska L, Turunen O, Bakker den M, Zwarthoff E, Lutchman M, Rouleau GA, Jääskeläinen J, Vaheri A, et al. 1997. Neurofibromatosis 2 tumor suppressor protein colocalizes with ezrin and CD44 and associates with actin-containing cytoskeleton. Journal of Cell Science 110: 2249-2260.

Sauer T, Pedersen MK, Ebeltoft K, Naess O. 2005. Reduced expression of Claudin-7 in fine needle aspirates from breast carcinomas correlate with grading and metastatic disease. Cytopathology 16: 193-198.

Schackmann RCJ, Klarenbeek S, Vlug EJ, Stelloo S, van Amersfoort M, Tenhagen M, Braumuller TM, Vermeulen JF, van der Groep P, Peeters T, et al. 2013. Loss of p120- 
catenin induces metastatic progression of breast cancer by inducing anoikis resistance and augmenting growth factor receptor signaling. Cancer Res 73: 4937-4949.

Schackmann RCJ, van Amersfoort M, Haarhuis JHI, Vlug EJ, Halim VA, Roodhart JML, Vermaat JS, Voest EE, van der Groep P, Van Diest PJ, et al. 2011. Cytosolic p120catenin regulates growth of metastatic lobular carcinoma through Rock1-mediated anoikis resistance. J Clin Invest 121: $3176-3188$.

Schmelzle T, Mailleux AA, Overholtzer M, Carroll JS, Solimini NL, Lightcap ES, Veiby OP, Brugge JS. 2007. Functional role and oncogene-regulated expression of the BH3-only factor Bmf in mammary epithelial anoikis and morphogenesis. Proc Natl Acad Sci 104: 3787-3792.

Schneider MR, Dahlhoff M, Horst D, Hirschi B, Trülzsch K, Müller-Höcker J, Vogelmann R, Allgäuer M, Gerhard M, Steininger S, et al. 2010. A key role for E-cadherin in intestinal homeostasis and Paneth cell maturation. PLOS ONE 5: e14325.

Shapiro L, Weis WI. 2009. Structure and biochemistry of cadherins and catenins. Cold Spring Harb Perspect Biol 1: a003053-a003053.

Shaw RJ, Paez JG, Curto M, Yaktine A, Pruitt WM, Saotome I, O’Bryan JP, Gupta V, Ratner N, Der CJ, et al. 2001. The Nf2 tumor suppressor, merlin, functions in Rac-dependent signaling. Dev Cell 1: 63-72.

Shiina H, Breault JE, Basset WW, Enokida H, Urakami S, Li LC, Okino ST, Deguchi M, Kaneuchi M, Terashima M, et al. 2005. Functional Loss of the gamma-catenin gene through epigenetic and genetic pathways in human prostate cancer. Cancer Res 65: 2130-2138.

Shimada S, Mimata A, Sekine M, Mogushi K, Akiyama Y, Fukamachi H, Jonkers J, Tanaka H, Eishi Y, Yuasa Y. 2012. Synergistic tumour suppressor activity of E-cadherin and p53 in a conditional mouse model for metastatic diffusetype gastric cancer. Gut 61: 344-353.

Sikora MJ, Jankowitz RC, Dabbs DJ, Oesterreich S. 2013. Invasive lobular carcinoma of the breast: Patient response to systemic endocrine therapy and hormone response in model systems. Steroids 78: 568-575.

Soto E, Yanagisawa M, Marlow LA, Copland JA, Perez EA, Anastasiadis PZ. 2008. p120 catenin induces opposing effects on tumor cell growth depending on E-cadherin expression. J Cell Biol 183: 737-749.

Stairs DB, Bayne LJ, pades B, Vega ME, Waldron TJ, Kalabis J, Klein-Szanto A, Lee J-S, Katz JP, Diehl JA, et al. 2011. Deletion of p120-catenin results in a tumor microenvironment with inflammation and cancer that establishes it as a tumor suppressor gene. Cancer Cell 19: 470-483.

Strasser A, Cory S, Adams JM. 2011. Deciphering the rules of programmed cell death to improve therapy of cancer and other diseases. EMBO J 30: 3667-3683.

Strathdee G. 2002. Epigenetic versus genetic alterations in the inactivation of E-cadherin. Semin Cancer Biol 12: 373-379.

Strumane K, Berx G, Van Roy F. 2004. Cadherins in cancer. Handb Exp Pharmacol 165: 69-103.

Suzuki A, Ohno S. 2006. The PAR-aPKC system: Lessons in polarity. J Cell Sci 119: 979-987.
Tada H, Hatoko M, Tanaka A, Kuwahara M, Muramatsu T. 2000. Expression of desmoglein I and plakoglobin in skin carcinomas. J Cutan Pathol 27: 24-29.

Tenhagen M, Klarenbeek S, Braumuller TM, Hofmann I, van der Groep P, Hoeve Ter N, van der Wall E, Jonkers J, Derksen PWB. 2016. p120-catenin is critical for the development of invasive lobular carcinoma in mice. J Mammary Gland Biol Neoplasia 1-8.

Thoreson MA, Reynolds AB. 2002. Altered expression of the catenin p120 in human cancer: Implications for tumor progression. Differentiation 70: 583-589.

Tinkle C, Lechler T, Pasolli H, Fuchs E. 2004. Conditional targeting of E-cadherin in skin: Insights into hyperproliferative and degenerative responses. Proc Natl Acad Sci 101: $552-557$.

Tomizawa Y, Ocque R, Ohori NP. 2012. Orbital metastasis as the initial presentation of invasive lobular carcinoma of breast. Intern Med 51: 1635-1638.

Totsukawa G, Yamakita Y, Yamashiro S, Hartshorne D, Sasaki Y, Matsumura F. 2000. Distinct roles of ROCK ( $\rho$-kinase) and MLCK in spatial regulation of MLC phosphorylation for assembly of stress fibers and focal adhesions in 3T3 fibroblasts. J Cell Biol.

Tunggal JA, Helfrich I, Schmitz A, Schwarz H, Günzel D, Fromm M, Kemler R, Krieg T, Niessen CM. 2005. E-cadherin is essential for in vivo epidermal barrier function by regulating tight junctions. EMBO J 24: 1146-1156.

Vaillant F, Merino D, Lee L, Breslin K, Pal B, Ritchie ME, Smyth GK, Christie M, Phillipson LJ, Burns CJ, et al. 2013. Targeting BCL-2 with the BH3 mimetic ABT-199 in estrogen receptor-positive breast cancer. Cancer Cell 24: $120-129$.

van de Ven RAH, Tenhagen M, Meuleman W, van Riel JJG, Schackmann RCJ, Derksen PWB. 2015. Nuclear p120catenin contributes to anoikis resistance of lobular breast cancer through Kaiso-dependent Wnt11 expression. Dis Model Mech 8: 373-384.

van de Wetering M, Barker N, Harkes IC, van der Heyden M, Dijk NJ, Hollestelle A, Klijn JG, Clevers H, Schutte M. 2001. Mutant E-cadherin breast cancer cells do not display constitutive Wnt signaling. Cancer Res 61: 278-284.

van der Post RS, Vogelaar IP, Carneiro F, Guilford P, Huntsman D, Hoogerbrugge N, Caldas C, Schreiber KEC, Hardwick RH, Ausems MGEM, et al. 2015. Hereditary diffuse gastric cancer: Updated clinical guidelines with an emphasis on germline $\mathrm{CDH} 1$ mutation carriers. J Med Genet 52: 361-374.

Van Keymeulen A, Lee MY, Ousset M, Brohée S, Rorive S, Giraddi RR, Wuidart A, Bouvencourt G, Dubois C, Salmon I, et al. 2015. Reactivation of multipotency by oncogenic PIK3CA induces breast tumour heterogeneity. $\mathrm{Na}$ ture 525: 119-123.

Visvader JE, Stingl J. 2014. Mammary stem cells and the differentiation hierarchy: Current status and perspectives. Genes Dev 28: 1143-1158.

Vleminckx K, Vakaet L, Mareel M, Fiers W, Van Roy F. 1991. Genetic manipulation of E-cadherin expression by epithelial tumor cells reveals an invasion suppressor role. Cell 66: 107-119.

Vlug E, Ercan C, Wall E, Diest PJ, Derksen PWB. 2013a. Lobular breast cancer: Pathology, biology, and options for clinical intervention. Arch Immunol Ther Exp 1-15. 
H.C. Bruner and P.W.B. Derksen

Vlug EJ, Ven RAH, Vermeulen JF, Bult P, Diest PJ, Derksen PWB. 2013b. Nuclear localization of the transcriptional coactivator YAP is associated with invasive lobular breast cancer. Cell Oncol (Dordr) 36: 375-384.

Vos C, Cleton-Jansen A, Berx G, de Leeuw W, Haar ter N, Van Roy F, Cornelisse C, Peterse J, van de Vijver M. 1997. E-cadherin inactivation in lobular carcinoma in situ of the breast: An early event in tumorigenesis. Br J Cancer 76: 1131-1133.

Wada K-I, Itoga K, Okano T, Yonemura S, Sasaki H. 2011. Hippo pathway regulation by cell morphology and stress fibers. Development 138: 3907-3914.

Wicki A, Niggli V. 2001. The $\rho / \rho$-kinase and the phosphatidylinositol 3-kinase pathways are essential for spontaneous locomotion of Walker 256 carcinosarcoma cells. Int J Cancer 91: 763-771.

Williams G, Williams E-J, Doherty P. 2002. Dimeric versions of two short N-cadherin binding motifs (HAVDI and INPISG) function as N-cadherin agonists. J Biol Chem 277: 4361-4367.

Winn RA, Bremnes RM, Bemis L, Franklin WA, Miller YE, Cool C, Heasley LE. 2002. $\gamma$-Catenin expression is re- duced or absent in a subset of human lung cancers and reexpression inhibits transformed cell growth. Oncogene 21: 7497-7506.

Xue B, Krishnamurthy K, Allred DC, Muthuswamy SK. 2012. Loss of Par3 promotes breast cancer metastasis by compromising cell-cell cohesion. Nat Cell Biol 15: 189-200.

Yamada S, Nomoto S, Fujii T, Takeda S, Kanazumi N, Sugimoto H, Nakao A. 2007. Frequent promoter methylation of M-cadherin in hepatocellular carcinoma is associated with poor prognosis. Anticancer Res 27: 2269-2274.

Yanagisawa M, Anastasiadis PZ. 2006. p120 catenin is essential for mesenchymal cadherin-mediated regulation of cell motility and invasiveness. J Cell Biol 174: 1087-1096.

Yap A, Niessen C, Gumbiner B. 1998. The juxtamembrane region of the cadherin cytoplasmic tail supports lateral clustering, adhesive strengthening, and interaction with p120ctn. J Cell Biol 141: 779-789.

Ying H, Biroc SL, Li WW, Alicke B, Xuan JA, Pagila R, Ohashi Y, Okada T, Kamata Y, Dinter H. 2006. The $\rho$ kinase inhibitor fasudil inhibits tumor progression in human and rat tumor models. Mol Cancer Therapeut 5: $2158-2164$. 


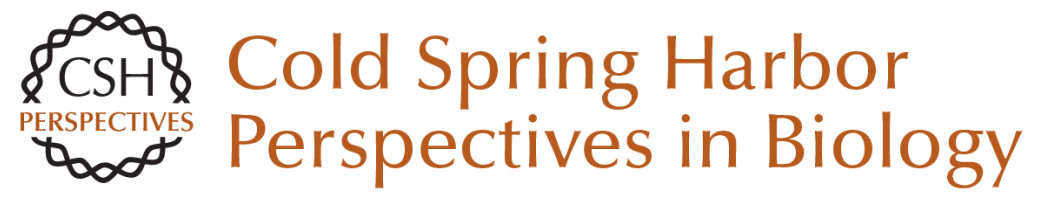

\title{
Loss of E-Cadherin-Dependent Cell-Cell Adhesion and the Development and Progression of Cancer
}

\author{
Heather C. Bruner and Patrick W.B. Derksen
}

Cold Spring Harb Perspect Biol 2018; doi: 10.1101/cshperspect.a029330 originally published online May 15,2017

\section{Subject Collection Cell-Cell Junctions}

Vascular Endothelial (VE)-Cadherin, Endothelial

Adherens Junctions, and Vascular Disease Maria Grazia Lampugnani, Elisabetta Dejana and Costanza Giampietro

Adherens Junctions and Desmosomes Coordinate Mechanics and Signaling to Orchestrate Tissue Morphogenesis and Function: An Evolutionary Perspective Matthias Rübsam, Joshua A. Broussard, Sara A. Wickström, et al.

Cell-Cell Contact and Receptor Tyrosine Kinase Signaling Christine Chiasson-MacKenzie and Andrea I. McClatchey

Hold Me, but Not Too Tight--Endothelial Cell-Cell Junctions in Angiogenesis

Anna Szymborska and Holger Gerhardt

Connexins and Disease

Mario Delmar, Dale W. Laird, Christian C. Naus, et al.

Cell Junctions in Hippo Signaling Ruchan Karaman and Georg Halder
Signaling by Small GTPases at Cell-Cell Junctions: Protein Interactions Building Control and Networks Vania Braga

Making Connections: Guidance Cues and Receptors at Nonneural Cell-Cell Junctions lan V. Beamish, Lindsay Hinck and Timothy E. Kennedy

The Cadherin Superfamily in Neural Circuit Assembly James $D$. Jontes

Mechanosensing and Mechanotransduction at Cell-Cell Junctions Alpha S. Yap, Kinga Duszyc and Virgile Viasnoff

Beyond Cell-Cell Adhesion: Sensational

Cadherins for Hearing and Balance Avinash Jaiganesh, Yoshie Narui, Raul Araya-Secchi, et al.

Cell-Cell Junctions Organize Structural and Signaling Networks Miguel A. Garcia, W. James Nelson and Natalie Chavez

For additional articles in this collection, see http://cshperspectives.cshlp.org/cgi/collection/

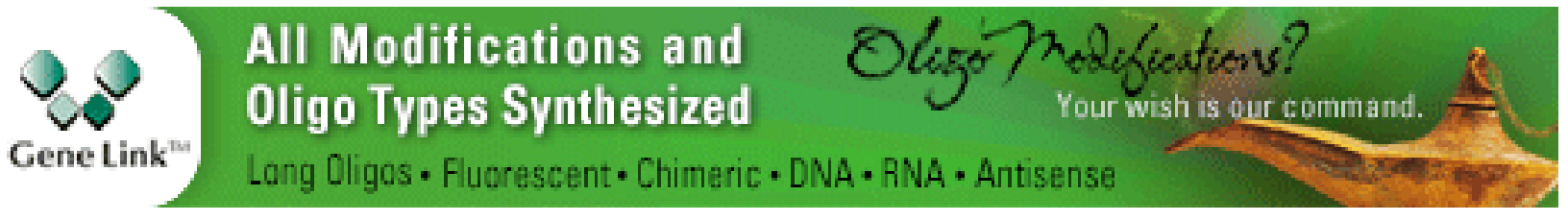


Loss of E-Cadherin-Dependent Cell-Cell Adhesion and the Development and Progression of Cancer Heather C. Bruner and Patrick W.B. Derksen

Desmosomes and Intermediate Filaments: Their Consequences for Tissue Mechanics

Mechthild Hatzfeld, René Keil and Thomas M. Magin
Cell Biology of Tight Junction Barrier Regulation and Mucosal Disease

Aaron Buckley and Jerrold R. Turner

Integration of Cadherin Adhesion and

Cytoskeleton at Adherens Junctions

René Marc Mège and Noboru Ishiyama

For additional articles in this collection, see http://cshperspectives.cshlp.org/cgi/collection/

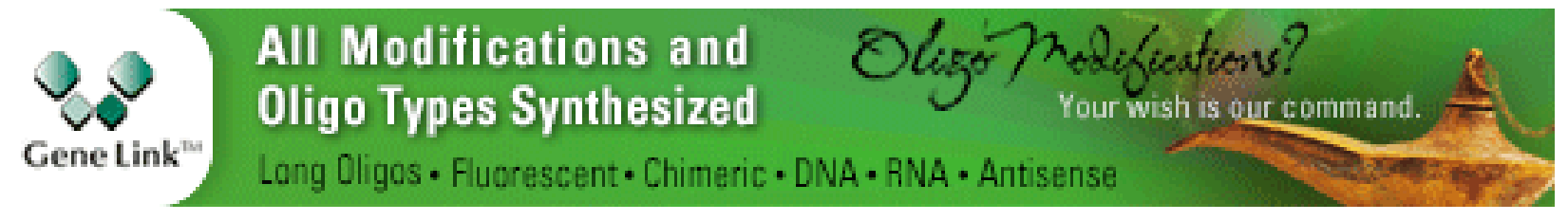

Copyright @ 2018 Cold Spring Harbor Laboratory Press; all rights reserved 